\title{
NUTRIÇÃO MINERAL, CRESCIMENTO E QUALIDADE DO ÓLEO ESSENCIAL DA MENTA (Mentha arvensis L.) CULTIVADA EM SOLUÇÃO NUTRITIVA
}

NIISON BORIINA MATA

Engenheiro Agrônomo

Oriemtedbr. Prof. Dr. QUIRINO A. C. CARMELLO

Dissertaço apresentado à Escola Superior de Agricultura "Luiz de Queiroz", da Universidade de S\$o Paulo, para obtencio do título de Mestre em Agronomia Área de Concentracio: Solos e Nutriço de Plantas

P I R A C I C A B A

Estado de S30 Paulo - Brasil

Oumbro de 1994 
Ficha catalogratica preparada pela Seça de Livros da Divisao de Eibliateca e Documentaçao - FCleilusF

Maia, Nilson Gorlina

Mzi7n Nutriçao mineral, crescimento e qualidade do oleo essencial da menta (fientha arvensis L.) cultivada em solucáo nutritiva. Firacicabas, 1994.

69p. ilus.

Diss. (Mestre) - ESALQ

Eibliografia.

1. Menta - Crescimento 2. Merta - Nutrifáo 3. Oleo essencial de merta - Qualidade I. Escala Superior de Agricultura Luiz de Queiroz, Firacicaba 


\section{NUTRIÇÃO MINERAL, CRESCIMENTO E QUALIDADE DO ÓLEO ESSENCIAL DA MENTA (Mentha arvensis L.) CULTIVADA EM SOLUÇÃO NUTRITIVA}

NILSON BORLINA MAIA

Engenheiro Agriacmo

Comissão julgadora:

Prof. Dr. Quirino Augusto de Camargo Carmello

ESALQ/USP

Prof. Dr. Antonio Roque Dechen

ESALQ/USP

Dr. Odair Alves Bovi 
Agradecimentos:

Agradeço a todos que direta ou indiretamente auxiliaram e possibilitaram a realização deste trabalho, especialmente aos colegas e amigos: Quirino A. C. Carmello, orientador deste trabalho; Odair Alves Bovi, Fernando Romariz Duarte, Maria Beatriz Calheiros, Hilda M. da Silva Honório, Paula Durante, Marcel Milano e João Vieira Monteiro, da Seção de Plantas Aromáticas e Medicinais do LAC; Márcia O. M. Marques, da Seção de Fitoquímica do IAC; Heitor Cantarella, Celi Feitosa e Cleide A. Abreu, da Seção de Fertilidade do Solo e Nutrição de Plantas do LAC; Marilene Leão Alves Bovi da Seção de Plantas Tropicais do IAC; Lauro E. S. Barata do Laboratório de Produtos Naturais do Departamento de Química da UNICAMP; Valdemar Atílio Malavolta Jr., da Seção de Bacteriologia Fitopatológica do Instituto Biológico; Lurdes A. D. Gonzales, Nivanda M. de Moura, Femando Eder Ré e Ricardo de Souza Oliveira do Departamento de Química da ESALQ; Sonia Piedade, do Departamento de Estatística da ESALQ; Roberto Venceslau de Carvalho e Maria Isabel Francelli, do Departamento de Fitopatologia da ESALQ; Eliana M.G. Sabino, da Biblioteca da ESALQ; Cristina de Paiva Gonçalves, da Multiplica LTDA; a Vera Lúcia Aleixo Martins; ao Instituto Agronômico de Campinas, pelo apoio ao trabalho e ao CNPq, pela bolsa de estudo. 


\section{SUMÁRIO}

Página

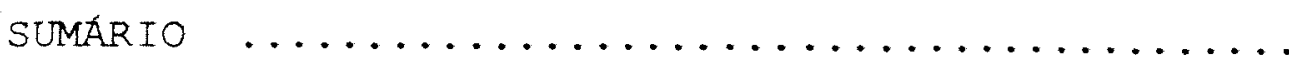

RESUMO

2. REVISÃo DE LITERATURA $\ldots \ldots \ldots \ldots \ldots \ldots \ldots \ldots$

2.1. Histórico sobre a planta de menta......... 3

2.2. Usos do óleo $\ldots \ldots \ldots \ldots \ldots \ldots \ldots \ldots \ldots$

2.3. Qualidade do óleo $\ldots \ldots \ldots \ldots \ldots \ldots \ldots \ldots$

2.4. Nutrição mineral $\ldots \ldots \ldots \ldots \ldots \ldots \ldots \ldots \ldots$

2.4.1. Nitrogênio $\ldots \ldots \ldots \ldots \ldots \ldots \ldots$

2.4.2. Fósforo $\ldots \ldots \ldots \ldots \ldots \ldots \ldots \ldots$

2.4.3. Potássio $\ldots \ldots \ldots \ldots \ldots \ldots \ldots \ldots \ldots$

2.4 .4 . Ferro $\ldots \ldots \ldots \ldots \ldots \ldots \ldots \ldots \ldots \ldots$

2.4 .5 . Zinco $\ldots \ldots \ldots \ldots \ldots \ldots \ldots \ldots \ldots \ldots \ldots \ldots \ldots$

2.4 .6 . Boro $\ldots \ldots \ldots \ldots \ldots \ldots \ldots \ldots \ldots \ldots$

3. MATERIAL E METODOS ................... 14

3.1. Variedade e obtenção do material ........ 14

3.2. Plantio $\ldots \ldots \ldots \ldots \ldots \ldots \ldots \ldots \ldots \ldots \ldots \ldots$

3.3. Tratamentos e soluções nutritivas ....... 15

3.4. Colheita das plantas $\ldots \ldots \ldots \ldots \ldots \ldots \ldots$ 
3.5. Doença bacteriana $\ldots \ldots \ldots \ldots \ldots \ldots \ldots \ldots .18$

3.6. Destilação do óleo $\ldots \ldots \ldots \ldots \ldots \ldots \ldots .18$

3.7. Análise cromatográfica do óleo $\ldots \ldots \ldots \ldots .18$

3.8. Análise química das plantas ........... 19

3.9. Delineamento experimental e análise estatística 20

4. RESULtados E DISCUSSÃo $\ldots \ldots \ldots \ldots \ldots \ldots \ldots \ldots \ldots$

4.1. Sintomas visuais de deficiência $\ldots \ldots \ldots . .21$

4.2. Produção de material seco $\ldots \ldots \ldots \ldots \ldots .25$

4.2.1. Planta inteira $\ldots \ldots \ldots \ldots \ldots \ldots .25$

4.2.2. Folhas $\ldots \ldots \ldots \ldots \ldots \ldots \ldots \ldots \ldots \ldots$

4.2.3. Hastes $\ldots \ldots \ldots \ldots \ldots \ldots \ldots \ldots \ldots \ldots$

4.2.4. Estolóes $\ldots \ldots \ldots \ldots \ldots \ldots \ldots \ldots$. 29

4.2.5. Raizes $\ldots \ldots \ldots \ldots \ldots \ldots \ldots \ldots \ldots$. 30

4.3. Teores de nutrientes $\ldots \ldots \ldots \ldots \ldots \ldots \ldots .30$

4.3.1. Folhas $\ldots \ldots \ldots \ldots \ldots \ldots \ldots \ldots \ldots$. 30

4.3.2. Hastes $\ldots \ldots \ldots \ldots \ldots \ldots \ldots \ldots \ldots .6 \ldots \ldots$

4.3.3. Estoloes $\ldots \ldots \ldots \ldots \ldots \ldots \ldots \ldots \ldots .34$

4.3.4. Raizes $\ldots \ldots \ldots \ldots \ldots \ldots \ldots \ldots \ldots .36$

4.3.5. Planta inteira $\ldots \ldots \ldots \ldots \ldots \ldots .38$

4.4. Quantidade de nutrientes $\ldots \ldots \ldots \ldots \ldots \ldots . . .6$

4.4.1. Folhas ................. 39

4.4.2. Hastes $\ldots \ldots \ldots \ldots \ldots \ldots \ldots \ldots, 41$

4.4.3. Estolóes $\ldots \ldots \ldots \ldots \ldots \ldots \ldots \ldots$. 43

4.4.4. Raízes $\ldots \ldots \ldots \ldots \ldots \ldots \ldots \ldots$. 45

4.4.5. Planta inteira $\ldots \ldots \ldots \ldots \ldots \ldots .47$ 
4.5. Doença bacteriana $\ldots \ldots \ldots \ldots \ldots \ldots \ldots \ldots$

4.6. Qualidade do óleo essencial ........... 49

4.6.1. Análise multidimensional ....... 52

4.6 .2 . Limoneno $\ldots \ldots \ldots \ldots \ldots \ldots \ldots \ldots$

4.6 .3 . Mentona $\ldots \ldots \ldots \ldots \ldots \ldots \ldots \ldots \ldots$

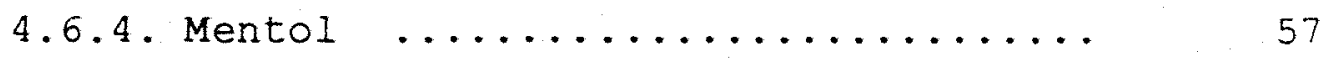

4.6 .5 . Metil acetato $\ldots \ldots \ldots \ldots \ldots \ldots \ldots . \ldots$

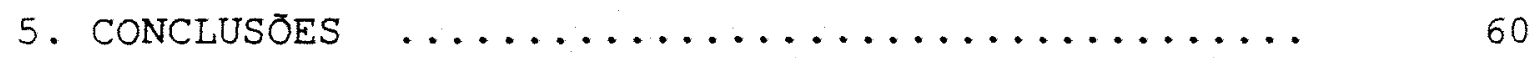

REFERENCIAS BIBLIOGRAFICAS $\ldots \ldots \ldots \ldots \ldots \ldots \ldots \ldots$ 


\title{
NUTRIÇÃO MINERAL, CRESCIMENTO E QUALIDADE DO ÓLEO ESSENCIAL DA MENTA (Mentha arvensis L.) CULTIVADA EM SOLUÇÃO NUTRITIVA
}

\author{
Autor: NILSON BORLINA MAIA \\ Orientador: Prof. Dr. QUIRINO A. C. CARMELLO
}

\section{RESUMO}

Para determinação do efeito de nutrientes na qualidade do óleo essencial da Mentha arvensis, cultivou-se plantas submetidas a oito tratamentos em solução nutritiva completa, com omissão de nitrogênio, fósforo, potássio, cálcio, ferro, zinco e boro.

O óleo essencial das folhas de cada tratamento foi extraido por destilação de arraste de vapor e analisado por cromatógrafo acoplado a espectrômetro de massa (GCMS).

A análise indicou sensiveis diferenças quanto ao número de componentes e à proporção de limoneno, mentona, mentol e metil acetato no óleo.

Determinou-se também efeitos da omissão de nutrientes no desenvolvimento de folhas, hastes, estolōes e raízes das plantas e as suas respectivas extrações de nutrientes.

Sintomas visuais de deficiência de nitrogênio, fósforo, potássio e cálcio foram observados e descritos. 


\title{
NUTRITION, GROWTH AND ESSENTIAL OIL QUALITY OF MINT (Mentha arvensis L.) IN NUTRIENT SOLUTION
}

\author{
Author: NILSON BORLINA MAIA \\ Adviser: Dr. QUIRINO A. C. CARMELLO
}

\section{SUMMARY}

To determinate the effect of the macro and micronutrients on the Mentha arvensis essential oil, plants were submitted to complete nutrient solution or without $\mathrm{N}, \mathrm{P}, \mathrm{K}, \mathrm{Ca}$, $\mathrm{Fe}, \mathrm{Zn}$ and $\mathrm{B}$.

Essential oil extracted by hydrodestillation was analyzed by gas chromatography and mass spectrometry. Oil nutrient omission influenced oil quality affecting concentrations of limonene, menthone, menthol and menthyl acetate.

Nutrient omission altered leaves, shoots, rhizomes and roots development as their respective nutrient extraction.

This work also describes visual symptoms of nitrogen, phosphorous, potassium and calcium deficiencies. 


\section{INTRODUÇĀO}

A menta (Mentha arvensis L.), é uma planta aromática da familia Labiatae, da qual se extrai, por processo de arraste de vapor relativamente simples, um óleo essencial rico em mentol. Este produto tem larga aplicaçăo nas indústrias de alimentos, farmacêutica, de higiene e do tabaco. O subproduto do processo de purificação de mentol, o óleo dementolado, também tem grande valor industrial.

Durante a II Grande Guerra Mundial, devido às limitaçōes comerciais com o Oriente, o Brasil tornou-se o principal produtor de óleo de menta e mentol. Vários fatores levaram o pais a perder essa posição, sendo os mais importantes, a associação da cultura com a fronteira agricola, que na época deslocou-se do Oeste paulista para o Paraguai, e o advento do mentol sintético que fez com que os preços diminuissem.

Mesmo assim, o mentol natural, extraido principalmente da $M$. arvensis L., continua tendo um papel muito importante devido a sua qualidade, simplicidade e baixo custo de produção nas regiões em que é cultivada (BRODERICK, 1993). O mentol sintético somente encontra mercado quando há elevaçōes excessivas no preço do natural (GREENHALG, 1979). Segundo CLARK (1994), a mentona, um outro componente deste óleo, tem o mesmo comportamento. 
A cultura da menta deslocou- se rapidamente da primeira regiăo onde foi plantada no Estado de São Paulo, em direção às novas fronteiras agrícolas, que no periodo de 1940 a 1970 encontravam-se no Oeste do Paraná e no Paraguai. O tipo de solo, clima e os sistemas de produção utilizados nessas regiões, provocaram perdas de nutrientes por erosão e lixiviação. Essas perdas deixaram os solos menos férteis e sem condições de dar suporte a lavouras produtivas, o que fez com que os produtores procurassem novas áreas para exploração.

Para substituir a grande quantidade de nutrientes perdida nas cinzas das matas queimadas, responsáveis pela produtividade mais elevada, é necessário a aplicação de altas doses de adubos orgânicos ou minerais, os quais podem ter influência sobre a qualidade do óleo essencial.

O mentol, apesar de ser o componente presente em maior quantidade no óleo, não é suficiente para definir a sua qualidade. Outras substâncias, presentes em pequenas porcentagens, têm grande importância, sendo que pequenas alterações nas suas quantidades podem alterar significativamente a qualidade do óleo.

A proporção entre todos esses componentes é variável em função de vários fatores ambientais, sendo a nutrição da planta um dos mais importantes.

Neste trabalho procura-se determinar os efeitos da omissão de alguns macro e micronutrientes da solução mutritiva no crescimento e na qualidade do óleo essencial da menta. 


\section{REVISĀO DE LITERATURA}

Apesar do homem utilizar e estudar os aromas de plantas desde o início das civilizações mais antigas, a literatura cientifica concernente, quando comparada com a das grandes culturas, é bastante restrita e está dispersa em obras e periódicos, nem sempre especificos.

No Brasil, faltam obras que cubram satisfatoriamente o assunto, a despeito da importância e da grande variabilidade das espécies aromáticas que aqui ocorrem.

\subsection{Histórico da planta de menta}

Os primeiros registros da ocorrência da $M$. arvensis datam do século $I$, quando o sacerdote japonês Enzan levou a planta da China para seu país e plantou-a nas cercanias de Kyoto, para usar suas folhas no chá. Somente por volta de 1870 relata-se um aumento expressivo na área plantada, próximo à cidade de Yamagata e posteriormente, em 1892, são feitos cultivos experimentais em diversas ilhas do arquipélago (GUENTHER, 1949). 
No Brasil, a menta passou a ser cultivada em pequena escala pelos primeiros imigrantes japoneses, que a trouxeram para o interior do Estado de São Paulo no começo do século. As restrições comerciais impostas aos produtos japoneses durante as guerras Sino-japonesa e II Guerra Mundial causaram escassez do óleo de menta e do mentol no mundo todo, elevando seus preços e estimulando os agricultores, japoneses imigrados para o Brasil, a cultivarem a menta em escala industrial (LIMA \& MOLLAN, 1952).

SANTOS (1993) menciona que as primeiras plantaçōes surgiram na região de Presidente Prudente, SP, em 1925. GUENTHER (1949), afirma que as primeiras plantações brasileiras de M. arvensis, foram feitas na Fazenda São Bartolomeu no municipio de Paraguaç, SP, mostrando concordância entre os autores quanto à região pioneira no seu plantio. $O$ autor acrescenta que, a partir dessa região, o cultivo da menta avançou para o Norte do Estado do Paraná, estabelecendo-se por fim no Paraguai. No Brasil ela foi intensamente cultivada entre os anos de 1963 e 1975, quando então seu cultivo começou a entrar em declínio.

GREENHALGH (1979) compara o Brasil com os Estados Unidos, onde as lavouras também se deslocaram em direção aos solos virgens recem-desmatados. No Brasil, esse deslocamento teria sido provocado, além da exaustão do solo citado por HUET (1972), também pelo ataque da ferrugem da menta (Puccinia menthae), segundo SANTOS (1993).

Dois países destacaram-se na sucessão do Brasil como principais fornecedores mundiais: China e Paraguai, havendo dúvidas se o primeiro pernaneceria na posição devido às políticas internas de produção então adotadas (KIEFER, 1986). 
Mais recentemente, a produção de menta tem se concentrado no Norte da Índia, onde, segundo vários autores, apresenta grande importância econômica e social (DUHAN et al., 1977; KOTHARI et al., 1987a e NAIR et al., 1991).

A melhoria da posição brasileira no mercado de óleo essencial depende da retomada da produção agrícola de $M$. arvensis. Para isso, é necessário que sejam solucionados alguns problemas de fertilidade, que foram os principais responsáveis pelo deslocamento da cultura para o Paraguai, conforme indica a literatura.

\subsection{Usos do óleo}

Os principais usos do mentol podem ser observados na Tabela 1.

Tabela 1: Consumo de mentol por tipo de produto (t/ano) e região.

\begin{tabular}{|c|c|c|c|c|c|c|}
\hline \multirow{2}{*}{ PRODUTO } & \multicolumn{6}{|c|}{ REGIĀO } \\
\hline & AMÉR N. & EUROPA & $\underline{\text { ASIA }}$ & AMÉR S. e C. & OUTROS & TOTAL \\
\hline TABACO & 800 & 100 & 300 & 100 & 50 & 1350 \\
\hline HIGIENE BUCAL & 350 & 500 & 450 & 300 & 250 & 1850 \\
\hline FARMACOS & 200 & 400 & 750 & 100 & 100 & 1550 \\
\hline CONFEITOS & 80 & 100 & 200 & 140 & 50 & 570 \\
\hline CREME BARBEAR & 50 & 80 & 40 & 50 & 30 & 250 \\
\hline OUTROS & 20 & 20 & 10 & 10 & 20 & 80 \\
\hline TOTAL & 1500 & 1200 & 1750 & 700 & 500 & 5650 \\
\hline
\end{tabular}

Fonte: Clark (1988).

O óleo essencial de menta e o mentol podem ser usados ainda numa infinidade de outros produtos, pois seu efeito sobre os microorganismos pode ser aproveitado de várias maneiras. SINGH et al. (1983) demonstram o efeito fungicida e fungistático desses óleos sobre 23 espécies, entre elas Alternaria sp., Curvularia lunauta, Fusarium moniliformae, $F$. solami e Rizoctonia bataticola. Os autores usaram 
concentraçōes variando de 500 a 10.000 ppm de óleo de menta nos respectivos meios de cultura, e observaram inibição de $100 \%$ dos micélios, a partir de $2.000 \mathrm{ppm}$, o que os levou a afirmar que "o óleo de Mentha arvensis, devido à sua forte atividade fungicida e largo espectro de atividade, superior a alguns fungicidas comerciais, pode ser usado como um forte produto no controle de doenças de plantas e animais."

SNGH et al. (1992) concluem que o óleo de menta, além de antifüngico, desempenha um papel antibacteriano, controlando o desenvolvimento de Salmonella sp. e Staphylococcus sp. Entre os fungos, controlou-se Alternaria sp. Fusarium sp, Cochiliobolus sativus, Sclerotium rolfsii e Aspergillus parasiticus. Os autores também sugerem o seu uso direto sobre grăos e alimentos armazenados, visando o controle de microorganismos e insetos,

\subsection{Qualidade do óleo essencial}

O óleo essencial é uma mistura de compostos de diversas naturezas acumulados pela planta. Normaimente estes compostos não têm função direta nas principais atividades bioquímicas da planta, como fotossintese, respiração, proteosintese, etc. Por isso os estudos na área são mais restritos e somente mais recentemente têm recebido maior atençăo (CONN, 1981).

Outro fator responsável pelo avanço nas determinações da composição do óleo essencial e, conseqüentemente, da sua qualidade, é a evoluçăo tecnologica dos equipamentos analíticos modernos que permitem uma melhor separaça dos componentes, conforme demonstra MAIA al. (1991). Por esses motivos os trabalhos sobre o assunto são relativamente recentes e escassos. 
Apesar dessas limitações, determinou-se muitos fatores que alteram a composição do óleo essencial, tais como o fotoperíodo descrito por CLARK \& MENARY, (1979) e SINHA \& SINGH (1984); a temperatura (HERALTH et al., 1979); o regime hidrico (CHARLES et al., 1990) o método de irrigação (DUHAN et al., 1977); e a variedade plantada (DONALísIO et al., 1985), entre outros.

GUENTHER (1949), descreve o óleo essencial de menta com as seguintes características fisicas:

Peso especifico a $25^{\circ} \mathrm{C}$ 0,876 a 0,898

Rotação Optica $-29^{\circ} 12^{\prime}$ a $-42^{\circ} 48^{\prime}$

Índice de refração 1,14577 a 1,14695

Teor de mentol total 65,2 a $88,9 \%$

Teor de ester (metil acetato) 4,5 a $18,9 \%$

\subsection{Nutrição mineral}

Há muito tempo, a Mentha arvensis já foi definida por vários autores como sendo uma planta muito exigente quanto à nutrição (FINNEMORE, 1926; GUENTHER, 1949). Porém, poucos são os trabalhos sobre nutrição, encontrados na literatura. A Índia destacou-se na produção de artigos científicos sobre a nutrição de menta, a partir da década de 1980 , sendo mais frequentes os trabalhos do ${ }^{n}$ Central Institute of Medicinal And Aromatic Plants" em Pantnagar, Utta Pradesh, no Norte do Pais, próximo ao Himalaia.

Não foram encontrados na literatura, estudos sobre o efeito do $\mathrm{Ca}, \mathrm{Mg}$ e $\mathrm{S}$ em Mentha arvensis. Quanto aos micronutrientes, somente $\mathrm{Fe}, \mathrm{Zn}$ e $\mathrm{B}$ foram 
estudados com mais detalhes. Um único trabalho, o de FAROOQI \& MISRA (1983) estudou, ainda que superficialmente, o desenvolvimento da planta em função desses três micronutrientes e também $\mathrm{Cu}, \mathrm{Mn}$ e Mo.

\subsubsection{Nitrogênio}

Entre todos os nutrientes, o $\mathrm{N}$ é o que apresenta a maior resposta positiva sobre a produção de massa verde de menta. Isso se deve a uma somatória de fatores fisiológicos, que interagem com o nitrogênio e contribuem para que a planta sintetise mais açúcares, aminoácidos e ácidos nucléicos, resultando em uma maior massa total da planta. Trabalhos de vários autores demonstram esse fato.

KOTHARI et al. (1987b) mostram que as variedades melhoradas respondem melhor às altas doses de $N(150 \mathrm{~kg} / \mathrm{ha})$ do que a variedade padrăo, deixando claro que a resposta da planta à presença do nutriente tem uma forte interação com as suas caracteristicas genéticas.

Existe fortes interações entre o nitrogênio disponivel e outros fatores de produção. KHERA et al (1986), demonstraram interações entre $\mathrm{N}$ e a irrigação. RAM et al. (1989) observaram que a forma e época de cobertura com aforma do adubo comum, granulado ou supergranulado recoberto. Esses trabalhos conduzem à inferência de que a omissão ou a deficiência de $\mathbf{N}$ na nutrição da menta limitará bastante a produção de folhas, hastes, raizes e rizomas.

Quanto aos aspectos qualitativos, SINGH \& SINGH (1968a) estudaram doses variáveis no intervalo de 0 a $200 \mathrm{~kg} / \mathrm{ha}$ de $\mathrm{N}$ e observaram que o teor de mentol no óleo essencial permaneceu inalterado em todos os tratamentos. 
A falta de outro fator nutricional como o fósforo, por exemplo, tem grande interação com o metabolismo do nitrogênio, o que compromete a sintese de aminoácidos e diminui a produção de proteínas. Desse modo, como demonstraram SINGH \& SINGH (1968a), a produção de massa verde da planta fica bastante comprometida por uma série de efeitos fisiológicos.

\subsubsection{Fósforo}

A importância do fósforo nas diversas reações bioquimicas dependentes de energia fica evidente, em vários trabalhos científicos.

Plantas de menta cultivadas em um meio pobre em fósforo, são caracterizadas por terem um desenvolvimento alterado, tendo menos folhas, menor área foliar, menor massa de matéria seca e verde. Os sintomas foliares da deficiência consistem em folhas velhas mais verdes, que se tornam avermelhadas e as hastes mais lenhosas. A altura da planta não chega a ser alterada (SINGH \& SINGH, 1968a). Os autores ainda concluiram que a deficiência do elemento compromete a planta em qualquer que seja seu estádio de desenvolvimento.

A falta de fósforo, além de alterar as reaçð̃es bioquimicas energéticas em que está diretamente associado, altera o metabolismo de outros nutrientes, como mostraram SINGH \& SINGH (1968a), num experimento onde a falta do nutriente afetou o nitrogênio, resultando em acúmulo de bases aminadas, aminoácidos e no empobrecimento na formação de proteínas.

SINGH \& SINGH (1968a) demonstraram a importância do fósforo no metabolismo dos carboidratos, tais como frutose, glucose, sacarose e açúcares redutores 
na Mentha arvensis. Nesse trabalho, a deficiência do elemento causou um acúmulo dos açúcares em todos os órgãos da planta, que foi mais evidente nas hastes. Os autores apresentaram duas explicações para esse fato: a interferência na sintese de proteinas no estádio de redução do nitrato e o acúmulo de aminoácidos.

Por ser um elemento tão importante em funções básicas do desenvolvimento da planta, o método e a forma de aplicação dos adubos fosfatados em culturas de menta são determinantes no rendimento da lavoura. KOTHARI et al. (1987a) demonstraram em um ensaio de campo na Índia, que a altura da planta e o rendimento de óleo estão significativamente correlacionados com a profundidade de aplicação do fertilizante fosfatado e a distância entre $o$ adubo e as linhas de plantio. Os melhores resultados foram obtidos quando o fertilizante foi colocado a $15 \mathrm{~cm}$ de profundidade e à igual distância lateral do centro da linha de mudas.

Quanto à quantidade de fósforo necessária, SUBRAHMANYAM et al. (1991), observaram em um ensaio de campo de dois anos no Norte da Índia, que a dose de $30 \mathrm{~kg} / \mathrm{ha}$ de $\mathrm{P}$ foi responsável pela maior produção de matéria seca da parte aérea e maior produção total de óleo.

\subsubsection{Potássio}

O estudo do efeito do potássio sobre a menta quando cultivada em solução nutritiva, tem mostrado que esse nutriente tem influência significativa sobre 0 metabolismo do nitrogênio, a taxa de respiração e o teor de óleo essencial. SINHA \& SINGH (1984) mostraram que as plantas cultivadas nessas condições, com omissão de $\mathrm{K}$, acumularam nitrogênio amoniacal, a partir de 60 dias do plantio, independentemente da época do ano em que ela foi cultivada. O teor de óleo essencial em plantas deficientes 
em $\mathbf{K}$ foi mais alto, porém seu efeito na redução da área foliar foi muito grande, o que reduziu consideravelmente a produção de óleo por planta e por área cultivada.

\subsubsection{Ferro}

O efeito do ferro na nutrição da menta foi bastante estudado na Índia, onde recomenda-se a aplicação de ate $55 \mathrm{~kg} / \mathrm{ha}$ de $\mathrm{FeSO}_{4}$ (NAIR et al. 1991).

A omissão de Fe na solução nutritiva reportada no trabalho de FAROOQI \& MISRA (1983) causou uma redução significativa de $50 \%$ no teor de óleo essencial nas folhas frescas. NAIR et al. (1991) e MISRA \& SHARMA (1991a) também detectaram efeitos semelhantes.

Tal fato pode ser entendido na demonstraca de SRIVASTAVA \& LUTHRA (1993). Trabalhando com ${ }^{14} \mathrm{CO}_{2}$ em Mentha piperita, demonstraram que a sintese de óleo essencial é dependente de enèrgia. No experimento as plantas deficientes em Fe reduzem drasticamente a quantidade de $\mathrm{CO}_{2}$ fixado como açúcares e portanto a disponibilidade de energia e o óleo produzido.

MISRA (1990) mostrou que a falta de Fe alterou a morfologia dos cloroplastos das células do mesófilo foliar, os quais ficaram pequenos e retorcidos. Os tilacoides apresentaram-se inchados e mal formados. Além disso, o número médio de cloroplastos por célula que normalmente é de 16 , foram reduzidos a 9 nas plantas deficientes. $\mathrm{O}$ autor descreveu as plantas cultivadas em ausência de $\mathrm{Fe}$, como reduzidas em menos da metade do tamanho das plantas normais e com uma severa clorose internerval seguida de necrose característica. 
MISRA \& SHARMA (1991a) mostraram um aumento significativo da matéria seca, em função das concentrações crescentes de $\mathrm{Fe}$ em solução nutritiva, determinando como $5,6 \mathrm{mg} / \mathrm{l}$ o nivel crítico de Fe na solução nutritiva.

\subsubsection{Zinco}

O Zinco é importante para a menta cultivada nos solos de aluvião do Norte da Índia, que são pobres no elemento (MISRA \& SHARMA, 1991b). Esses autores, estudando plantas cultivadas em solução nutritiva sem $\mathrm{Zn}$, descreveram os seguintes sintomas visuais de deficiência: folhas pequenas com clorose internerval no terceiro par de folhas e internódios curtos. FAROOQI \& MISRA (1983), descreveram que as plantas apresentaram também um aspecto raquitico com baixa produção de massa verde.

MISRA \& SHARMA (1991b) determinaram a concentração crítica de Zn nas folhas como $28,0 \mathrm{mg} / \mathrm{kg}$ e na solução em $0,0475 \mathrm{mg} / \mathrm{l}$ de $\mathrm{Zn}$, que foi semelhante ao nível encontrado por SUBRAHMANYAN et al. (1991). Nessas concentrações do nutriente, o teor de mentol foi mais alto. Houve, também, resposta significativa do teor de óleo à aplicação complementar de Zn nas plantas deficientes, mas o teor de mentol no óleo não foi alterado com as complementações.

SUBRAHMANYAN et al. (1991) sugeriram aplicaçð̃es de $Z n$ nas regiões de solos pobres no elemento e justificaram tal operação como responsável por uma maior disponibilidade de $\mathrm{P}$ para a planta.

Segundo NAIR et al. (1991), essas respostas da menta à aplicação de $\mathrm{Zn}$ são devidas às altas doses de NPK nos solos de origem calcária. Nesse trabalho, os autores chegam a recomendar aplicações de solução com 10ppm de sulfato de zinco. 


\subsubsection{Boro}

A deficiência de Boro em Mentha piperita cultivada em solução nutritiva por FISCHER \& HECHT-BUCHHOLZ (1985) causou, principalmente, má formação das paredes celulares das glândulas oleiferas, que ficaram muito delgadas ainda na fase inicial de formação. $O$ citoplasma destas células mostrou severos sinais de degradação, quando ainda jovens, tornando-se semelhantes aos das células em senescência de plantas normais. As plantas com deficiência de B tem um curto periodo em que conseguem acumular o óleo essencial, o que afeta drasticamente o rendimento e levou os autores a recomendarem a aplicação do nutriente ao solo.

FISCHER \& BUSSLER (1984) descreveram os mesmos efeitos do Boro nas glândulas oleiferas de $M$. piperita, além de alterações nos tecidos vasculares, que passaram a acumular substâncias escuras e a apresentar decréscimos na produção de óleo essencial.

Anteriormente, LEE \& ARNOFF (1967), sugeriram que a deficiência de Boro teria um efeito inibidor sobre a enzima 6-fosfogluconato desidrogenase, o que resultaria em excesso de ácidos fenólicos, que por sua vez, causariam necrose de tecidos e até a morte da planta.

FAROOQI \& MISRA (1983) observaram em $M$. arvensis, uma redução significativa na altura da planta da ordem de $30 \%$. O número de perfilhos também foi reduzido de 21 nas plantas controle para 10 nas plantas deficientes. 


\section{MATERIAL E MÉTOdOS}

\subsection{Variedade utilizada e obtenção do material}

A variedade IAC-701 da espécie Mentha arvensis foi a utilizada, por ser a mais adaptada às condiç̃es brasileiras, pela boa produção, teor de mentol e óleo, e pela resistência à ferrugem.

A variedade foi multiplicada nos canteiros da Seção de Plantas Aromáticas e Medicinais do Instituto Agronômico em Campinas SP, entre os meses de janeiro e maio de 1994. Os estolóes utilizados no plantio foram colhidos e limpos no dia 2 de maio de 1994 e estocados em recipiente úmido durante um dia.

\subsection{Plantio}

O experimento foi instalado na casa de vegetação da Seção de Fertilidade do Solo do Instituto Agronômico, no Município de Campinas, SP, no dia 3 de maio de 1994. 
Os recipientes utilizados para o plantio da menta foram vasos metálicos, revestidos com material inerte, com capacidade para 6 litros de quartzo moido, que foi enxaguado 15 vezes com água destilada durante a semana que precedeu a instalação do experimento.

Em cada vaso foram plantados 8 estolões com 3 gemas cada um, à profundidade de $2,5 \mathrm{~cm}$, dispostos em circulos.

\subsection{Tratamentos e soluções nutritivas}

Após o plantio, cada vaso recebeu diariamente a solução nutritiva de seu tratamento, em quantidade suficiente para que começasse a drenar o excesso pelo orificio do fundo do vaso. As Tabelas 2 e 3 identificam e quantificam as soluções e os tratamentos aplicados.

Tabela 2: Composição das soluçð̃es em função dos tratamentos (ml/).

SOLUÇÃO

ESTOOUEM

$\mathrm{KH}_{7} \mathrm{PO}_{4}$

$\mathrm{KNO}_{3}$

$\mathrm{Ca}\left(\mathrm{NO}_{3}\right)$ )

$\mathrm{MgSO}_{4}$

$\mathrm{KCl}$

$\mathrm{CaCl}$,

$\mathrm{NH}_{4} \mathrm{H}_{7} \mathrm{PO}_{4}$

$\mathrm{NH}_{4} \mathrm{NO}_{3}$

$\left(\mathrm{NH}_{4}\right)_{2} \mathrm{SO}_{4}$

$\mathrm{Mg}\left(\mathrm{NO}_{3}\right)$ ?

Fe-EDTA *

micronutriente**

completo $\quad \underline{N}$

$\underline{\mathbf{P}}$

Ca

$\underline{\text { Fe }}$

$\underline{\mathrm{Zn}} \quad \underline{\mathrm{B}}$

micro $-\mathrm{Zn}$ **

micro - B **

- Preparada de acordo com SARRUGE (1975)

* Ver composiçáo na Tabela 3 
Tabela 3: Composição das soluções estoque para os tratamentos de omissão de micronutrientes $(\mathrm{g} /)$.

\begin{tabular}{|c|c|c|c|}
\hline \multirow{2}{*}{ REAGENTES } & \multicolumn{3}{|c|}{ TRATAMENTOS } \\
\hline & Completo e sem Fe & $\operatorname{sem} Z \mathbf{n}$ & $\operatorname{sen} B$ \\
\hline $\mathrm{H}_{3} \mathrm{BO}_{3}$ & 2,85 & 2,86 & - \\
\hline $\mathrm{MnCl}_{2} 4 \mathrm{H}_{2} \mathrm{O}$ & 1.81 & 1.81 & 1.81 \\
\hline $\mathrm{ZnCl}_{\text {, }}$ & 0,10 & - & 0,10 \\
\hline $\mathrm{CuCl}_{2}$ & 0,04 & 0,04 & 0,04 \\
\hline $\mathrm{H}_{3} \mathrm{MOO}_{4} \cdot \mathrm{H}_{7}$ & 0,02 & 0,02 & 0,02 \\
\hline
\end{tabular}

Os vasos que receberam tratamento sem nitrogênio, foram regados com solução completa durante 10 dias, entre 19 a 23 de maio e 13 a 17 de junho, pois a omissão completa do nutriente não permitia um desenvolvimento satisfatório para obtenção de material para as anállises químicàs e extração do óleo essencial.

\subsection{Colheita das plantas}

A parte aérea das plantas foi colhida entre os dias 19 e 20 de julho de 1994, com 77 e 78 dias de cultivo respectivamente, quando ainda não apresentavam, botões florais abertos, conforme o recomendado por SINGH \& SINGH (1989). Esta época coincidiu, com a preconizada por SINGH \& SINGH (1968a), que verificaram que por volta de 70 dias a $M$. anvensis cultivada em solução nutritiva e areia lavada apresentava o mais avançado estadio de maturação e o máximo acúmulo de óleo essencial. 
A colheita prematura deveu-se ao inicio de infestação de oidio (Oidium spp.). Avaliou-se que adiantando alguns dias a colheita previniria que o experimento fosse prejudicado por alta infecção füngica ou por contaminação do óleo essencial por algum produto quimico a ser usado no controle da doença.

A colheita da parte aérea consistiu no corte do colo da planta próximo à areia. Procedeu-se em seguida a separação das partes, contagem, determinação da massa e do comprimento das folhas, hastes, brotações primárias e secundárias. Os diferentes órgãos foram embalados, secos em estufa com circulação forçada de ar a $65-70^{\circ} \mathrm{C}$, e moidos para a análise química.

Os seguintes parâmetros de crescimento das plantas foram avaliados em cada vaso:

- Altura das hastes, do colo até o último par de folhas abertas, ou altura da planta;

- Comprimento das brotações laterais, medidas da inserção na haste principal até o último par de folhas abertas;

- Peso total das folhas;

- Peso de 50 discos para o cálculo da área foliar,

- Peso dos estolסes e soma do comprimento de todos os estolóes de cada vaso;

- Peso das raizes.

Somente uma parte das folhas foi separada para a determinação de massa seca e encaminhada ao laboratório para análise química. $O$ restante foi embalado em sacos plásticos, identificado, comprimido manualmente para eliminação do ar interno e armazenados em congelador à temperatura de $-15^{\circ} \mathrm{C}$ até o momento da.extração do óleo essencial por arraste de vapor. 


\subsection{Doenca bacteriana}

As plantas tratadas com solução sem cálcio apresentaram sintomas típicos de ataque bacteriano, cuja confirmação se deu pela observação microscópica, apresentada na Figura 8.

Procedeu-se aos postulados de Koch, em hospedeiro sadio, em condições de casa de vegetação, para a confirmação de patogenicidade. Para identificação da bactéria foram realizados testes segundo as metodologias de LELLIOT \& STEAD (1987) e SCHAAD (1988).

\subsection{Destilação do óleo}

As folhas congeladas de cada vaso foram destiladas em aparetho de Clevenger durante uma hora. $O$ início da destilação foi considerado o momento da condensação da primeira gota. $O$ óleo coletado foi lacrado em ampolas de $1 \mathrm{ml}$ e mantido em refrigerador até a análise cromatográfica.

\subsection{Ansilise cromatográfica do óleo}

O óleo essencial extraido das folhas de três repetições de cada tratamento, foi analisado no Laboratório de Produtos Naturais do Instituto de Quimica 
da Universidade de Campinas (UNICAMP), em cromatógrafo de gás acoplado ao espectrômetro de massa (modelo HP 5970), dotado de coluna capilar DB-5 (25m X $0,25 \mathrm{~mm}$ ), com aumento de temperatura programada a $4^{\circ} \mathrm{C} / \mathrm{min}$ de 50 a $170^{\circ} \mathrm{C}$ e $10^{\circ} \mathrm{C} / \mathrm{min}$ de $170-270^{\circ} \mathrm{C}$, injetor a $250^{\circ} \mathrm{C}$ e gás hélio de arraste com fluxo de $1 \mathrm{ml} / \mathrm{min}$.

$O$ óleo essencial foi dissolvido em acetato de etila, para evitar que a água remanecente da destilação degradasse a coluna capilar do cromatógafo. Amostras de 1 microlitro dessa mistura foram injetadas no aparelho para análise cromatográfica.

\subsection{Análise química das plantas}

As diferentes partes das plantas: folhas, hastes, rizomas e raizes, foram encaminhadas ao laboratório da Seção de Fertilidade do Solo e Nutrição de Plantas do Instituto Agronômico, Campinas, SP, para a determinação de B, N e obtenção de extratos para a análise dos demais nutrientes, segundo metodologia descrita por BATAGLIA et al. (1983).

Os extratos foram analisados pelo laboratório do Setor de Nutrição Mineral de Plantas do Departamento de Química da Escola Superior de Agricultura "Luiz de Queiróz" em Piracicaba, SP, segundo metodologia descrita por SARRUGE \& HAAG (1974). 


\subsection{Delineamento experimental e análise estatística}

$\mathrm{O}$ experimento foi instalado e analisado em delineamento inteiramente casualizado, conforme recomendado por GOMES (1981), com 4 repetições de cada tratamento.

Os vasos foram redistribuidos semanalmente sobre a mesa da casa de vegetação, para se ter um melhor controle local e casualização.

Os resultados da qualidade do óleo essencial, obtidos nas análises cromatográficas foram avaliados por análise multidimensional conforme foi descrito por CANTAGREL \& LABLAMQUIE (1986). 


\section{RESULTADOS E DISCUSSĀO}

\subsection{Sintomas visuais de deficiência}

Nem todos os tratamentos de omissão apresentaram sintomas visiveis de deficiência. Somente os tratamentos sem nitrogènio, fósforo, potássio e cálcio apresentaram sintomas característicos, possíveis de observação durante a condução do experimento. A Figura 1 apresenta plantas com sintomas imediatamete antes da colheita. As plantas tratadas com solução completa apresentaram desenvolvimento normal, com boa coloração, tamanho e brotações. Após 30 a 40 dias do plantio os vasos apresentavam-se completamente cobertos pelas plantas.

As plantas cultivadas sem nitrogênio apresentaram desenvolvimento muito reduzido desde o início da brotação. As folhas, amareladas, não apresentavam a pilosidade caracteristica da espécie e ficaram mais arredondadas. As hastes não se desenvolveram, deixando a planta bastante baixa. Também não apresentavam brotações laterais, nem formação de estolões.

O pequeno desenvolvimento obtido, ocorreu somente após os periodos de aplicação da solução completa, necessária para se obter um mínimo de desenvolvimento. As Figuras 1 e 2 comparam o tratamento sem nitrogênio com os 
demais tratamentos que apresentaram sintomas de deficiência e com o tratamento completo.

Durante o decorrer do experimento, as plantas tratadas sem fósforo apresentavam folhas menores, mas com a mesma coloração e pilosidade das folhas tratadas com solução completa. Na época da colheita, as folhas mais velhas começavam a desenvolver uma coloração marrom na face dorsal A maior diferença das plantas deficientes ocorreu nas hastes, que ficaram mais avermelhadas e apresentavam raras e pequenas brotações laterais, conforme mostra a Figura 3. Muito semelhantes àquelas descritas por SINGH \& SINGH (1968a).

As plantas que receberam solução nutritiva sem potássio apresentaram, desde o início da brotação, um desenvolvimento mais lento e hastes menores, com poucas brotaçðes laterais; eram menores e com menos folhas do que as plantas do tratamento completo, similares às descritas por SINHA \& SINGH (1984). Na época da colheita, os vasos tinham o aspecto da Figura 4.

As folhas das plantas deste tratamento, antes mesmo do desenvolvimento completo da primeira haste, ficaram mais arredondadas, com pouca pilosidade, mais brilhantes e apresentavam manchas necróticas, com cerca de $1 \mathrm{~mm}$ de diâmetro, por todo o limbo.

A partir de 40 dias após o plantio, as manchas das extremidades das folhas situadas nas primeiras brotações, passaram a aumentar de tamanho, necrosando completamente as pontas e bordas das folhas mais velhas, tomando bastante característico o deslocamento do nutriente das folhas das brotações mais velhas para as folhas das brotações mais novas. A Figura 5 compara uma folha com esses sintomas e uma folha normal do tratamento completo. 
O primeiro sintoma visual detectado nas plantas tratadas com solução sem cálcio foi o desenvolvimento de uma bacteriose, cujos sintomas apareceram inicialmente nas folhas mais velhas, na base da planta. A necrose desenvolvia-se a partir das nervuras centrais, encurvando as folhas e acabando por tomar toda a superficie e, posteriormente, toda a haste atacada, conforme pode ser vista na Figura 6.

Somente as plantas do tratamento sem cálcio sofreram ataque bacteriano. Algumas plantas desse tratamento não apresentaram o sintoma acima, porém todas as plantas tiveram um desenvolvimento menor quanto à altura das plantas e à área foliar, conforme se vê na Figura 7. Já no final do experimento, as últimas folhas emitidas das hastes sobreviventes ao ataque bacteriano, apresentavam pequeno desenvolvimento, sendo retorcidas e quebradiças e com coloraçăo acinzentada. Alguns pares de folhas, mais velhas, desenvolveram uma clorose intemerval bastante acentuada.

As plantas cultivadas com solução sem ferro apresentaram um desenvolvimento normal. Observou-se porém em algumas plantas, uma coloração avermelhada nos nós das hastes.

Somente uma haste, de todos os vasos cultivados com solução sem zinco, apresentou folhas retorcidas e com aparência muito semelhante às plantas cultivadas sem cálcio. Porém, não se observou folhas e internós menores, ou a clorose nos pares de folhas mais novos como descreveu MISRA \& SHARMA (1991).

Os vasos tratados com solução sem boro, pareciam apresentar uma menor densidade de plantas, que, no entanto, não foi detectado nas medições após a colheita. Também não se observou internós menores, folhas arredondadas, nem clorose e necrose como os descritos por FISCHER \& BUCHHOLZ (1988). 

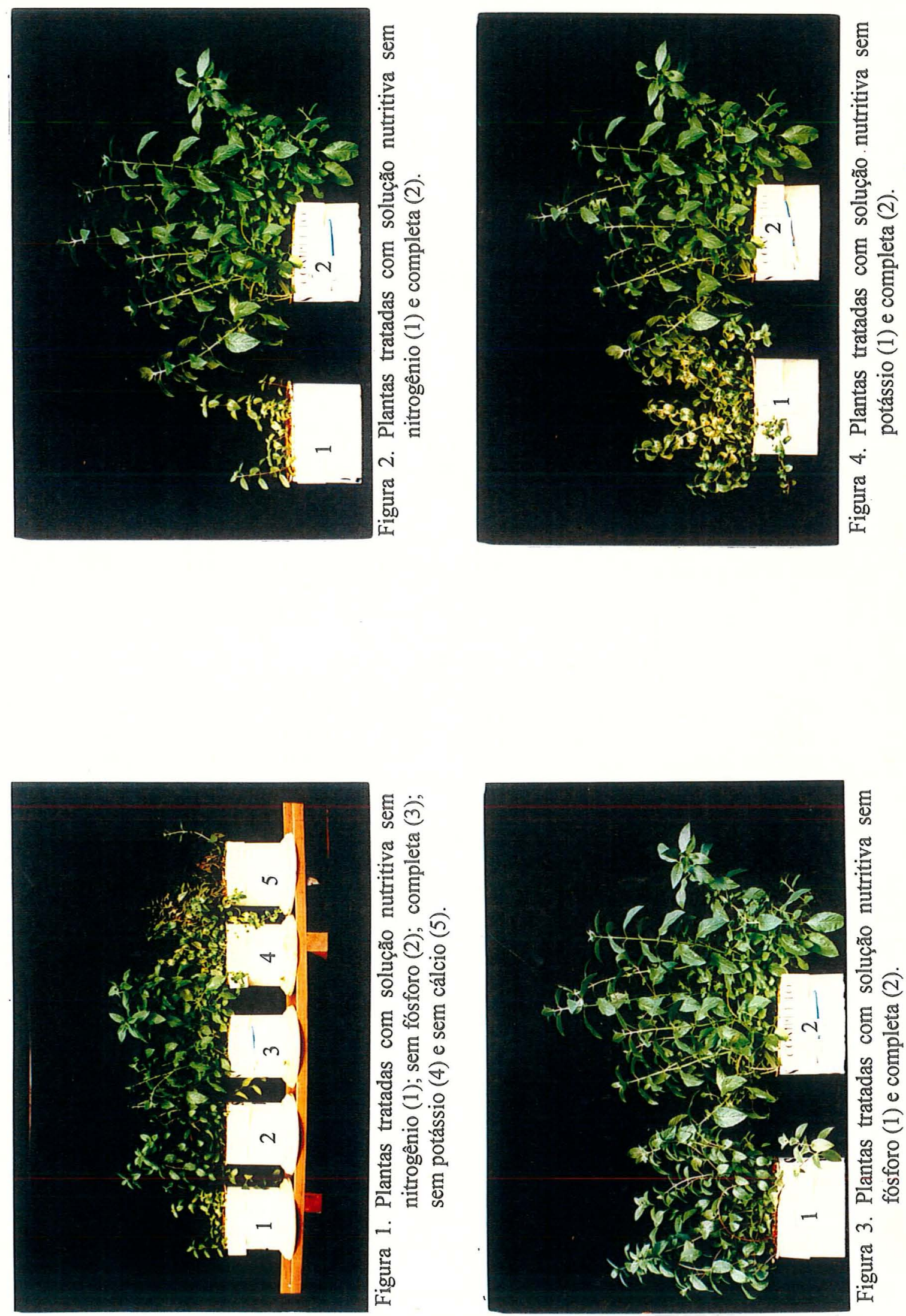


\subsection{Produção de material seco}

\subsubsection{Planta inteira}

A produção média de toda a massa de material seco por vaso do tratamento completo foi de $32,09 \mathrm{~g}$, que diferiu significativamente dos tratamentos com omissão de $\mathrm{K}$, Ca e N, conforme pode-se ver na Tabela 4. A queda significativa de produção de massa de material verde total observada por MISRA \& SHARMA (1991), quando omitiram zinco da solução nutritiva, não foi detectada neste trabalho. $O$ comportamento das plantas estudadas, em função da omissão de micromutrientes, foi mais próximo dos descritos por FAROOQI \& MISRA (1983), que não detectaram diferenças estatisticamente significativas.

Tabela 4. Produção média de massa de material seco (g), produzido por vaso.

\begin{tabular}{|c|c|c|c|c|c|c|c|c|c|}
\hline \multirow[b]{2}{*}{ Parte } & \multicolumn{8}{|c|}{ TRATAMENTOS } & \multirow[b]{2}{*}{$\underline{\text { DMS }}$} \\
\hline & Completo & $\operatorname{sen} N$ & $\operatorname{sen} P$ & $\operatorname{sen} \mathrm{K}$ & $\operatorname{sem~Ca}$ & $\operatorname{sem~Fe}$ & $\operatorname{sen} 2 n$ & $\operatorname{sem} B$ & \\
\hline Folhas & $10,6 \mathrm{a}$ & $0,5 d$ & $5,5 b c$ & $5,8 \mathrm{bc}$ & $3,3 \mathrm{~cd}$ & 8,3ab & $9,1 \mathrm{a}$ & $8,4 a b$ & 3,1 \\
\hline Hastes & $6,7 \mathrm{a}$ & $0,6 c$ & $2,7 \mathrm{bc}$ & $1,70 c$ & $2,1 b c$ & $4,1 a b$ & 6,72 & $3,4 a b c$ & 3,5 \\
\hline Estoldes & $11,2 \mathrm{a}$ & $0,8 d$ & $7,0 a b c$ & 3,6 bed & 1,9 d & $7,8 a b c$ & $8,5 a b$ & 6,8abod & 6,2 \\
\hline Raizes & 3,6abc & $0,6 \mathrm{c}$ & 4,9 & $0,9 c$ & $1,8 b c$ & $4,3 a b$ & $3,0 \mathrm{abc}$ & $4,1 \mathrm{ab}$ & 3,1 \\
\hline Total & 32,12 & $2,5 d$ & 20,1 sbe & 11,9 ad & $9,1 \mathrm{~cd}$ & 24,53 & 27,40 & $22,7 \mathrm{ab}$ & 12,0 \\
\hline
\end{tabular}

* DMS = Diferenca Mínima Significativa.

Obs.: Números seguidos da mesma letra nas linhas nåo diferem significativamente pelo teste de Tukey a $5 \%$. 

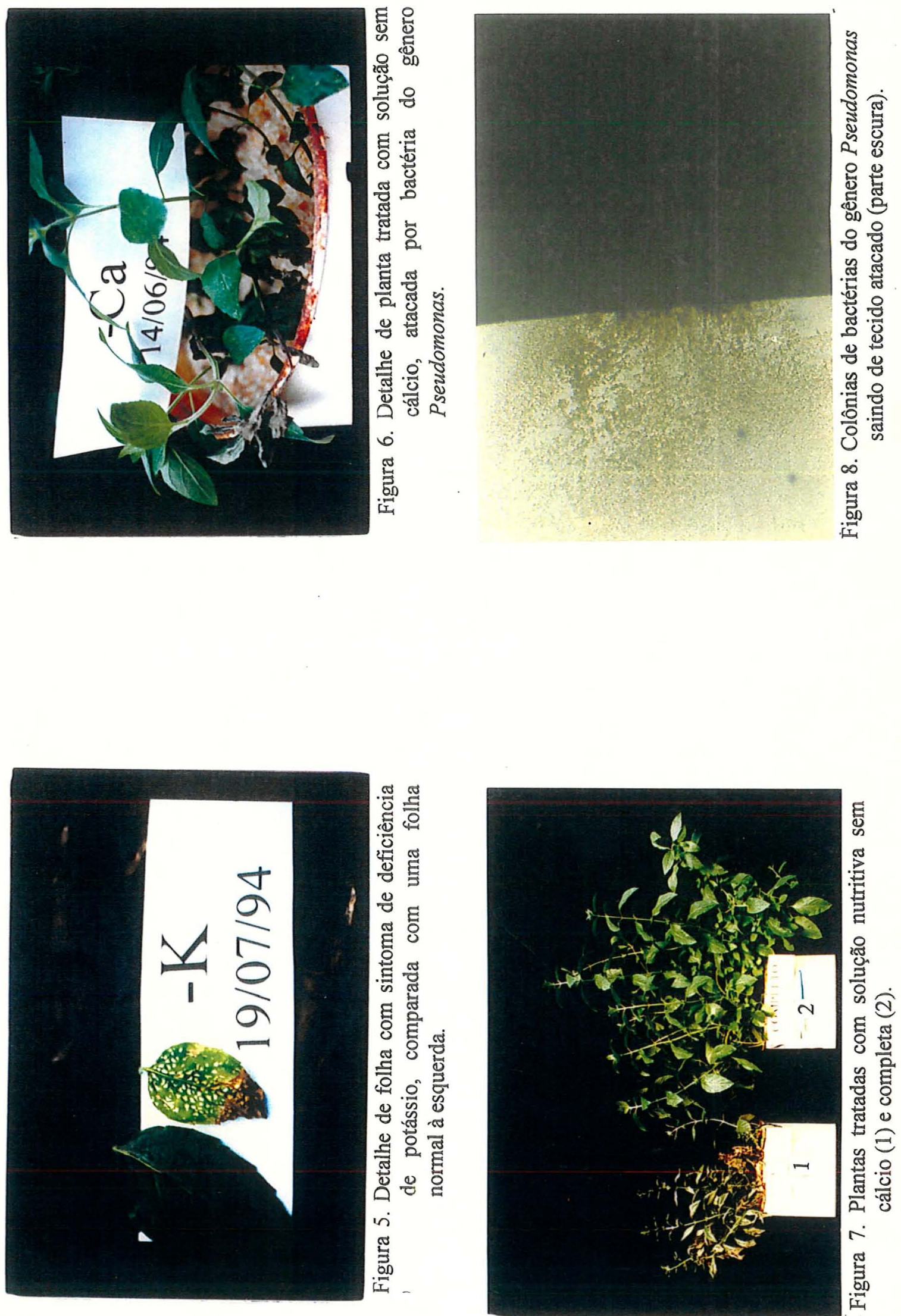
Nas plantas do tratamento completo, as raizes foram responsáveis por somente $11,28 \%$ do total da massa de material seco produzido. Esta baixa proporção de raizes pode ser o motivo da menta ser considerada uma planta exigente em fertilidade. Havendo uma pequena quantidade de raizes para absorver os nutrientes necessários para uma grande quantidade massa de material verde, a planta necessita ter à sua disposição uma maior quantidade de nutrientes.

A Tabela 5 apresenta a proporção de cada órgão em cada tratamento. Pode-se notar que a omissão de alguns nutrientes favoreceram ou prejudicaram, proporcionalmente, o desenvolvimento de órgãos distintos.

Tabela 6. Relação entre a massa dos órgãos e a planta inteira (\%) em função dos tratamentos.

\begin{tabular}{|c|c|c|c|c|c|}
\hline TRATAMENTO & FOLHAS & HASTES & & RAIZES & ESTOLÃO \\
\hline Completo & 33 & 21 & & 11 & 35 \\
\hline $\operatorname{sem} \mathbf{N}$ & 22 & 22 & & 23 & 33 \\
\hline $\operatorname{sem} P$ & 27 & 13 & & 24 & 35 \\
\hline $\operatorname{sem} \mathrm{K}$ & 49 & 14 & & 7 & 30 \\
\hline sem Ca & 36 & 23 & & 20 & 21 \\
\hline sem Fe & 34 & 17 & & 18 & 32 \\
\hline $\operatorname{sem} \mathbf{Z n}$ & 33 & 25 & & 11 & 31 \\
\hline $\operatorname{sem} B$ & 37 & 15 & & 18 & 30 \\
\hline
\end{tabular}

\subsubsection{Folhas}

A folha é o órgão de maior importância na planta, pois todo o óleo essencial encontra-se nela e a produção agrícola é também nela gerada. Neste experimento, as folhas representaram entre 49 e 22 do total da planta conforme mostra a Tabela 6. 
O efeito da omissão de nutrientes nas folhas foi muito semelhante ao efeito na planta inteira, sendo que a omissão de fósforo teve na produção de folhas um efeito negativo mais significativo. A Tabela 4 mostra esse efeito, sendo importante considerar-se que o tratamento sem cálcio foi prejudicado não só pela ausência do nutriente, mas também pelo ataque de bactérias que mataram as folhas durante o desenvolvimento da planta.

Os resultados obtidos são semelhantes aos de SINGH \& SINGH (1968a), que explicam a baixa produção das plantas tratadas sem nitrogênio e sem fósforo através do comprometimento da sintese de proteinas.

A área foliar e o mumero de pares de folhas foram proporcionais ao peso do matérial seco. O tratamento completo somou $4.511,08 \mathrm{~cm}^{2}$ e o sem nitrogênio $205,40 \mathrm{~cm}^{2}$. O número de pares de folhas por planta do tratamento completo foi de 28,81 e do tratamento sem nitrogênio de 6,40 . Os níveis de significância foram idênticos ao de massa de material seco das folhas.

\subsubsection{Hastes}

O comportamento das hastes em relação aos nutrientes omitidos nos tratamentos foi muito semelhante ao das folhas. Nenhum dos micronutrientes omitidos não causaram efeitos significativos. A Tabela 4 apresenta os resultados obtidos.

A importância desse órgão deve-se ao fato de ser o suporte das fothas, que têm interesse econômico, definem a altura da planta e a cobertura vegetal em função da suas brotações laterais. A Tabela 6 quantifica os resultados obtidos com esse órgão. 
O tamanho da haste principal é que determina a altura da planta e, como pode-se notar na Tabela 6 , ele foi significativamente menor nos tratamentos sem nitrogênio, potássio e fósforo.

O número de brotações laterais também foi um fator muito alterado em função da omissão de nutrientes. Na mesma tabela, observa-se que os três tratamentos que produziram plantas mais baixas também desenvolveram um menor número de brotações, cujo comprimento total também foi bem menor.

Os efeitos da omissão de micronutrientes sobre a altura e o número de hastes observados por FAROOQI \& MISRA (1983), não foi detectado neste trabalho.

Tabela 6. Número e comprimento (cm) das hastes principais e das brotações laterais em função dos tratamentos.

\begin{tabular}{|c|c|c|c|c|}
\hline \multirow[b]{2}{*}{ TRATAMENTO } & \multicolumn{2}{|c|}{ HASTE PRINCIPAL } & \multicolumn{2}{|c|}{ BROTACĀO LATERAL } \\
\hline & númerolvaso & $\begin{array}{l}\text { altura da planta } \\
(\mathrm{cm})\end{array}$ & número/vaso & $\begin{array}{c}\text { comprimento } \\
(\mathrm{cm})\end{array}$ \\
\hline Completo & $14 a b$ & $38,4 a b$ & $12 a$ & $\overline{393,3} \mathrm{abc}$ \\
\hline $\operatorname{sem} N$ & $10 \mathbf{a b}$ & $9,8 \quad \mathrm{e}$ & 0 & $0,0 \quad c$ \\
\hline $\operatorname{sem} P$ & $15 \mathrm{a}$ & 27,3 cd & 5 bcd & $101,8 \mathrm{c}$ \\
\hline $\operatorname{sem} K$ & $14 a b$ & $23,5 \quad d$ & $3 \mathrm{~cd}$ & 186,3 bc \\
\hline $\operatorname{sem} \mathrm{Ca}$ & $8 b$ & 30,9 bod & $8 a b c$ & $354,5 a b c$ \\
\hline sem Fe & $15 \mathrm{a}$ & $34,9 a b c$ & $7 \mathbf{a b c}$ & $427,0 a b c$ \\
\hline $\operatorname{sem} \mathrm{Zn}$ & $16 \mathrm{a}$ & $36,3 a b$ & $9 a b c$ & $729,9 \mathrm{ab}$ \\
\hline $\operatorname{sem} B$ & $12 a b$ & $35,6 \mathrm{ab}$ & $8 a b c$ & $535,6 a b c$ \\
\hline DMS & 7 & 7,7 & 6 & 582,4 \\
\hline
\end{tabular}

\subsubsection{Estolōes}

Os estolões são importantes não só como órgãos reprodutivos, mas também como órgãos de reserva. Neste experimento eles desenvolveram um tamanho 
considerável, dentro dos vasos com 6 litros de volume, chegando a somar mais de $12 \mathrm{~m}$ de comprimento.

O comprimento dos estolões foi diretamente proporcional à massa de material seco, e os valores obtidos estão na Tabela 4 .

\subsubsection{Raizes}

Somente a omissão de potássio e de nitrogênio afetaram significativamente a produção de raizes em relação às plantas do tratamento completo. Deve-se notar que a omissão de fósforo prejudicou significativamente a produção de matérial seco de folhas e hastes, a altura e a brotação lateral da planta, mas não prejudicou a produção de raizes, conforme mostra a Tabela 4.

\subsection{Teores de nutrientes}

\subsubsection{Folhas}

A Tabela 7 apresenta os teores de nutrientes analisados nas folhas em função dos tratamentos que receberam. A folha de menta foi o órgão que apresentou a maior concentração de nutrientes. Somente os teores de $\mathrm{P}$ foram semelhantes aos teores médios encontrados em toda a planta (Tabela 11). Os demais nutrientes têm teores médios nas folhas mais elevados, principalmente os micronutrientes. 
Tabela 7. Teores de nutrientes nas folhas em função dos tratamentos.

\begin{tabular}{|c|c|c|c|c|c|c|c|c|}
\hline \multirow[b]{2}{*}{ Nutriemes } & \multicolumn{8}{|c|}{ TRATAMENTOS } \\
\hline & Completo & $\operatorname{sen} P$ & $\operatorname{sen} K$ & $\operatorname{sen} \mathrm{Ca}$ & $\operatorname{sen} \mathrm{Fe}$ & $\operatorname{sen} 2 n$ & $\operatorname{sem} B$ & DMS* \\
\hline$N$ & $4,43 \mathrm{~cd}$ & $4,31 d$ & $4,71 \mathrm{bc}$ & $5,30 \mathrm{a}$ & 4.260 & $5,02 \mathrm{ab}$ & $4,77 b$ & 0,32 \\
\hline$P$ & $0,37 \mathrm{c}$ & $0,18 d$ & $0,51 a$ & $0,44 b$ & $0,39 \mathrm{bc}$ & $0,41 \mathrm{bc}$ & $\begin{array}{l}0,40 b \\
c\end{array}$ & 0,06 \\
\hline $\mathbf{K}$ & $4,21 \mathrm{c}$ & $4,28 \mathrm{c}$ & $0,45 d$ & $6,12 \mathrm{a}$ & $4,08 c$ & $4,67 \mathrm{~b}$ & $4,21 c$ & 0,27 \\
\hline $\mathrm{Ca}$ & $1,49 \mathrm{~cd}$ & $\begin{array}{l}1,58 b \\
c\end{array}$ & $1,95 \mathrm{a}$ & $1,51 \mathrm{~cd}$ & $1,41 d$ & $1,57 \mathrm{bc}$ & $1,40 \mathrm{~d}$ & 0,12 \\
\hline $\mathbf{M g}$ & $0,67 \mathrm{de}$ & $\begin{array}{l}0,71 c \\
d\end{array}$ & $1,31 \mathrm{a}$ & 0,640 & $0,76 b c$ & $0,81 b$ & $\begin{array}{l}0,72 c \\
d\end{array}$ & 0,06 \\
\hline $\mathrm{S}$ & $0,19 b c$ & $0,13 d$ & $0,18 c$ & $0,23 \mathrm{a}$ & $\begin{array}{l}0,20 a b \\
c\end{array}$ & $0,23 a$ & $\begin{array}{l}0,22 a \\
b\end{array}$ & 0,4 \\
\hline $\mathrm{Fe}$ & $432 d$ & $481 \mathrm{c}$ & $504 c$ & $650 a$ & $550 \mathrm{~b}$ & $553 \mathrm{~b}$ & $417 d$ & 37 \\
\hline $\mathrm{Zn}$ & $46 \mathrm{~b}$ & $68 a$ & $67 a$ & $58 a b$ & $31 \mathrm{c}$ & $52 b$ & 496 & 12 \\
\hline B & sle & $49 e$ & $\pi \mathbf{b}$ & $132 a$ & $68 c$ & 64d & $37 f$ & 4 \\
\hline Mn & 560 & $72 d$ & $131 b$ & 203a & $65 \mathrm{de}$ & $75 \mathrm{~d}$ & $70 \mathrm{de}$ & 19 \\
\hline $\mathrm{Cu}$ & $9 \mathrm{de}$ & $11 \mathrm{~b}$ & llb & $14 *$ & se & $11 \mathbf{b}$ & 9od & 1 \\
\hline
\end{tabular}

O desenvolvimento das plantas do tratamento sem nitrogênio foi tão afetado pela falta do nutriente, que não se conseguiu a quantidade de folhas necessárias para a análise química e para a destilação do óleo essencial. Como optou-se pela destilação somente das poucas folhas obtidas, não há resultados das concentrações de nutrientes nas folhas deste tratamento.

As folhas das plantas cultivadas na solução nutritiva sem fósforo tiveram um decréscimo significativo no teor de $\mathrm{S}$. Nota-se que $\mathrm{o}$ teor de $\mathrm{P}$ nas folhas foi bastante estável em todos os tratamentos, com excessão dos tratamentos de omissão de fósforo e potássio. Neste último, o teor de $\mathrm{P}$ nas folhas foi significativamente superior ao tratmento completo. Já os teores dos micronutrientes $\mathrm{Fe}, \mathrm{Zn}$ e $\mathrm{Cu}$ apresentaram um aumento significativo. 
A omissão de potássio ocasionou aumento significativo na concentração de quase todos os nutrientes, com exceção do S. SINHA \& SINGH (1984) mostraram dados semelhantes e determinaram que o aumento no teor de $\mathrm{N}$ deveu-se ao aumento de substâncias amoniacais nas folhas deficientes em $\mathrm{K}$.

As plantas do tratamento sem cálcio apresentaram um aumento significativo na concentração de quase todos os nutrientes analisados, com exceção do $\mathrm{Ca}$, P e $\mathrm{Zn}$, sendo que estes dois últimos apresentaram uma tendência de maior concentração. As folhas com teores mais altos de $\mathrm{N}(5,30 \%)$, de todo o experimento, foram as deste tratamento.

A omissão de ferro na solução nutritiva ocasionou aumento nas concentrações de $\mathrm{Mg}$, B e Fe nas folhas. É possivel que falhas no revestimento interno dos vasos metálicos tenham sido responsáveis pelo fornecimento do nutriente. Já o $\mathrm{Zn}$ sofreu um decrécimo significativo semelhante aos resultados publicados por SUBRAHMANYAM et al. (1991).

As folhas das plantas cultivadas no tratamento sem zinco apresentaram $5,02 \%$ de $\mathrm{N}$, um nivel tão alto quanto o do tratamento sem cácio. Houve ainda aumentos significativos nos teores de $\mathrm{Mg}, \mathrm{S}, \mathrm{Fe}, \mathrm{Mn}, \mathrm{B}$ e $\mathrm{Cu}$, sendo os teores do próprio zinco, semelhantes aos teores do tratamento completo.

A omissão de boro da solução nutritiva alterou significativamente somente a concentração de $\mathrm{B}$, que diminuiu, e a de $\mathrm{N}$ que aumentou, atingindo $4,77 \%$. 


\subsubsection{Hastes}

A Tabela 8 apresenta os teores médios dos nutrientes analisados nas hastes das plantas em função dos tratamentos que receberam. A pequena quantidade de material produzido no tratamento sem nitrogênio permitiu somente a determinação do teor de $\mathrm{B}$, que foi significativamente maior que o do tratamento completo e de $\mathrm{N}$, que apesar de ser bem menor, não diferiu do teor apresentado naquele tratamento.

Tabela 8 . Teores de nutrientes nas hastes em função dos tratamentos.

\begin{tabular}{|c|c|c|c|c|c|c|c|c|c|}
\hline \multirow[b]{2}{*}{ Nutrierte } & \multicolumn{9}{|c|}{ TRATAMENTOS } \\
\hline & Complato & $\operatorname{sen} N$ & $\operatorname{sem} P$ & $\operatorname{sen} K$ & $\operatorname{sen} C_{2}$ & sem Fe & $\operatorname{sen} \mathrm{Zn}$ & $\operatorname{sem~B~}$ & $\underline{\mathrm{DMS}^{*}}$ \\
\hline $\mathbf{N}$ & $2,08 c$ & $0,80 \mathrm{c}$ & $1,74 \mathrm{c}$ & $2,47 b c$ & $4,66 \mathrm{a}$ & $2,04 c$ & $4,26 a b$ & $2,26 \mathrm{c}$ & 1,82 \\
\hline $\mathbf{P}$ & 0,316 & nd. & $0,11 \mathrm{c}$ & $0,32 b$ & $0,47 a$ & $\mathbf{0 , 3 3 b}$ & $0,34 b$ & $\mathbf{a}, \mathbf{3 3 b}$ & 0,09 \\
\hline $\mathbf{K}$ & $3,86 b c$ & nd & $2,72 \mathrm{c}$ & $0,25 \mathrm{~d}$ & $6,02 \mathrm{a}$ & $3,64 b c$ & 4,596 & $4,36 b$ & 1,26 \\
\hline $\mathrm{Ca}$ & $0,94 \mathrm{~b}$ & nd. & $0,90 \mathrm{bc}$ & $0,61 d$ & $0,82 \mathrm{bc}$ & $0,82 \mathrm{bc}$ & $0,77 \mathrm{c}$ & $0,76 \mathrm{~cd}$ & 0,15 \\
\hline Mg & $0,40 t c$ & n.d. & $0,34 b c d$ & $0,78 \mathbf{a}$ & $0,33 \mathrm{~cd}$ & $0,44 b c$ & $0,49 \mathrm{~b}$ & $0,40 b c$ & 0,15 \\
\hline $\mathbf{S}$ & $0,12 \mathrm{~b}$ & nd. & $0,12 b$ & $0,14 b$ & $0,23 \mathrm{a}$ & $0,14 b$ & $0,13 b$ & $0,14 b$ & 0,05 \\
\hline $\mathrm{Fe}$ & $93 b c$ & nd. & $80 c$ & $145 \mathrm{a}$ & $140 \mathrm{a}$ & $84 c$ & $123 \mathrm{ab}$ & $87 b c$ & 37 \\
\hline Zn & $27 a b c$ & n.d. & $27 a b c$ & $43 a$ & $37 a b$ & $14 c$ & $22 \mathrm{bc}$ & $25 \mathrm{abc}$ & 21 \\
\hline B & $35 b$ & $55 \mathrm{a}$ & $20 d \mathrm{de}$ & $30 \mathrm{bc}$ & 24 ade & $25 \mathrm{sad}$ & 23 code & $15 \mathrm{e}$ & 9 \\
\hline $\mathbf{M n}$ & $19 \$$ & n.d. & $28 b$ & $35 \mathrm{~b}$ & $289 a$ & $20 \mathrm{~b}$ & $24 b$ & $23 b$ & 20 \\
\hline $\mathrm{Cu}$ & $7 a b c$ & n.d. & $8 \mathrm{a}$ & 6abc & $7 a b$ & $4 b c$ & $5 a b c$ & $3 c$ & 3 \\
\hline $\begin{array}{l}\text { Macronut } \\
\text { Micronutr } \\
\text { n.d. = náo } \\
* \text { DMS = } \\
\text { Obs } \cdot \text { Ním }\end{array}$ & $\begin{array}{l}\text { s expr } \\
\text { s expr } \\
\text { rming }\end{array}$ & $\begin{array}{l}\text { os } \mathrm{cm} \\
\mathrm{s} \mathrm{em}\end{array}$ & & & & & & & \\
\hline
\end{tabular}

As hastes das plantas do tratamento sem fósforo, em comparação às do tratamento completo, apresentaram teores menores somente de B e de P.

A omissão do potássio na solução nutritiva provocou diminuição nos teores de $\mathrm{Ca}$ e $\mathrm{K}$ nas hastes e o aumento de $\mathrm{Mg}$ eFe.

As plantas cultivadas no tratamento sem cálcio desenvolveram hastes mais pobres em B. Os nutrientes $\mathrm{N}, \mathrm{P}, \mathrm{K}, \mathrm{S}, \mathrm{Fe}$ e $\mathrm{Mn}$, como havia ocorrido nas folhas, 
aumentaram a concentração, destacando-se este último, que apresentou teor com $289 \mathrm{ppm}$, enquanto nas plantas do tratamento completo apresentou $19 \mathrm{ppm}$.

$\mathrm{O}$ teor dos nutrientes nas hastes das plantas cultivadas no tratamento sem ferro não foram diferentes das plantas do tratamento completo, exceto para B, que diminuiu.

A omissão do zinco na solução nutritiva, produziu hastes com teores maiores de $\mathrm{N}$ e $\mathrm{Fe}$ e menores em $\mathrm{Ca}$ e $\mathrm{B}$ que o tratamento completo.

A omissão de boro da solução nutritiva diminuiu significativamente o teor desse nutriente nas hastes bem como o teor de Ca.

\subsubsection{Estolōes}

A Tabela 9 apresenta os teores de nutrientes analisados nos estolðes, em função dos tratamentos que receberam. Os teores de $\mathrm{Fe}, \mathrm{Zn}, \mathrm{B}$ e $\mathrm{Cu}$ neste órgão foram maiores que na planta como um todo. Os demais mutrientes ocorreram em concentrações próximas das médias da planta inteira (Tabela 11). 
Tabela 9. Teores de nutrientes nos estolões em função dos tratamentos.

\begin{tabular}{|c|c|c|c|c|c|c|c|c|c|}
\hline \multirow[b]{2}{*}{ Vutrientes } & \multicolumn{9}{|c|}{ TRATAMENTOS } \\
\hline & Compteto & $\operatorname{sen} N$ & $\operatorname{sen} P$ & $\operatorname{sen} K$ & $\operatorname{setnCa}$ & $\operatorname{sem} F e$ & $\operatorname{sem} \mathrm{Zn}$ & $\operatorname{sem} B$ & $\underline{\text { DMS }}^{*}$ \\
\hline $\mathbf{N}$ & $2.00 \mathrm{bc}$ & $0,83 \mathrm{~d}$ & $1,77 \propto d$ & $2,80 \mathrm{ab}$ & $3,35 \mathrm{a}$ & $2,55 \mathrm{abc}$ & $2,11 b c$ & $2,05 \mathrm{bc}$ & 0,97 \\
\hline $\mathrm{P}$ & $0,31 b$ & $0,31 b$ & $0.14 c$ & $0,38 b$ & $0,47 \mathrm{a}$ & $0,38 b$ & $0,36 b$ & $0,36 b$ & 0,07 \\
\hline $\mathbf{K}$ & $3,90 \mathrm{ab}$ & $2,30 \mathrm{c}$ & $3,14 b$ & $0,70 \mathrm{~d}$ & $4,28 \mathrm{a}$ & $4,29 \mathrm{a}$ & $4,17 \mathrm{a}$ & $3,52 \mathrm{ab}$ & 0,80 \\
\hline $\mathrm{Ca}$ & $0.46 b$ & $0,46 b$ & $0,35 \mathrm{c}$ & $0,66 \mathrm{a}$ & $0,73 \mathbf{a}$ & $0,47 \mathrm{~b}$ & $0,45 \mathrm{bc}$ & $0,43 \mathrm{bc}$ & 0,10 \\
\hline $\mathbf{M g}$ & $0,35 \mathrm{bc}$ & $0,18 \mathrm{e}$ & $0,26 \mathrm{de}$ & $0,52 \mathrm{a}$ & 0,30 bod & $0,38 b$ & 0,34 bad & $0,29 \mathrm{od}$ & 0.08 \\
\hline$S$ & $0,14 a b c$ & $0,10 c$ & $0.13 b c$ & $0,17 a b$ & $0,19 a$ & $0,13 b c$ & $0,12 \mathrm{bc}$ & $0,13 b c$ & 0,05 \\
\hline $\mathrm{Fe}$ & $97 \mathrm{~b}$ & $142 b$ & $101 b$ & $124 b$ & $156 \mathrm{ab}$ & $89 \mathrm{~b}$ & $114 b$ & $314 a$ & 160 \\
\hline $\mathrm{Zn}$ & $17 \mathrm{de}$ & $46 a$ & 2lode & $31 \mathrm{bc}$ & $40 \mathrm{ab}$ & $12 e$ & $22 \mathrm{cde}$ & $35 b$ & 10 \\
\hline B & $33 \mathbf{a b}$ & $24 \mathrm{bc}$ & $17 \mathrm{c}$ & $28 a b c$ & $40 a$ & $31 a b c$ & $31 a b$ & $22 b c$ & 14 \\
\hline $\mathbf{M n}$ & $3 d$ & $12 \mathrm{bod}$ & God & $18 b$ & $78 \mathbf{2}$ & 8 od & $50 d$ & $13 \mathrm{bc}$ & 9 \\
\hline $\mathrm{Cu}$ & $6 a$ & $5 a$ & $6 *$ & 9. & $\mathbf{8 a}$ & 4a & 5. & 118 & 9 \\
\hline
\end{tabular}

A omissão do nitrogênio na solução nutritiva afetou a concentração de outros nutrientes nos estolōes. Além do próprio $\mathrm{N}$, que teve menos da metade da concentração dos estolōes do tratamento completo, houve uma diminuição significativa nos teores de $\mathrm{K}$ e $\mathrm{Mg}$. enquanto a concentração de $\mathrm{Zn}$ nesses tecidos apresentou um aumento de $16 \mathrm{ppm}$ no tratamento completo para 46ppm nesse tratamento.

A omissão do fósforo na solução nutritiva induziu à formação de estolðes com concentraç̃̃es mais baixas de $\mathrm{Ca}, \mathrm{Mg}$ e $\mathrm{B}$, além do próprio $\mathrm{P}$.

Os estolões das plantas cultivadas no tratamento sem potássio, apesar de bem menores, apresentaram concentração mais elevada de Ca, $\mathrm{Mg}, \mathrm{Zn}$ e $\mathrm{Mn}$, mostrando que o acúmulo desses nutrientes pela planta sofreu um efeito de diluição. Já o teor de K diminuiu.

Somente a falta de nitrogênio afetou mais a produção de estolões do que a omissão de cálcio. 
Os estolōes das plantas tratadas com solução nutritiva sem cálcio apresentaram os teores de Ca mais elevado que os das tratadas com solução completa. Além do $\mathrm{Ca}$, houve aumento nas concentrações de $\mathrm{N}, \mathrm{P}, \mathrm{Zn}$ e, principalmente, de $\mathrm{Mn}$ que passou de 3ppm nos estolões das plantas do tratamento completo para 78ppm nos estolões do tratamento sem cálcio, indicando uma possível estratégia da planta em concentrar nutrientes carentes nestes órgãos de reserva.

A omissão de boro na solução não afetou significativamente sua concentração nos estolðes, mas aumentou os teores de $\mathrm{Fe}, \mathrm{Zn}$ e $\mathrm{Mn}$ em relação aos estolōes das plantas do tratamento testemunha.

Os estolões das plantas tratadas com soluções nutritiva sem ferro e sem zinco, não diferiram quanto aos teores dos nutrientes analisados dos obtidos nas plantas do tratamento completo.

\subsubsection{Raizes}

A Tabela 10 apresenta os resultados dos teores de nutrientes analisados nas raizes em função dos tratamentos que receberam. A pequena quantidade de matéria seca de raizes das plantas cultivadas com solução nutritiva sem nitrogênio, possibilitou a determinação somente dos teores de $N$ e de $B$, sendo que este último foi significativamente maior que o do tratamento completo. 
Tabela 10. Teores de nutrientes nas raizes em função dos tratamentos.

\begin{tabular}{|c|c|c|c|c|c|c|c|c|c|}
\hline \multirow[b]{2}{*}{ Vutrientes } & \multicolumn{9}{|c|}{ TRATAMENTOS } \\
\hline & Completo & $\operatorname{sen} N$ & $\operatorname{sen} P$ & $\operatorname{sen} K$ & $\operatorname{sem} \mathrm{Ca}$ & $\operatorname{sem} \mathrm{Fe}$ & $\operatorname{sen} Z n$ & $\operatorname{sen} B$ & $\underline{\mathrm{DMS}}^{*}$ \\
\hline $\mathbf{N}$ & $1,75 b c$ & $1,10 c$ & $2,00 b$ & $2,14 b$ & $2.89 \mathrm{a}$ & $1.83 b$ & $2,05 b$ & $1,90 \mathrm{~b}$ & 0.66 \\
\hline $\mathrm{P}$ & $0.68 \mathrm{~s}$ & nd. & $0,11 \mathrm{c}$ & $0,75 a$ & $0,68 \mathrm{a}$ & $0,42 b$ & $0,68 a$ & $0,77 \mathbf{a}$ & 0,19 \\
\hline $\mathbf{K}$ & $3,25 b$ & nd. & $4,03 \mathrm{ab}$ & $0,38 \mathrm{c}$ & $3,83 a b$ & $3,27 \mathrm{~b}$ & $4.23 \mathrm{ab}$ & $3,82 \mathrm{ab}$ & 1,40 \\
\hline $\mathrm{Ca}$ & $1, \pi \mathfrak{a}$ & ad. & $1,10 b$ & $2,01 a$ & $0,53 c$ & $1,07 \mathbf{b}$ & $1,92 \mathrm{a}$ & $1,75 \mathrm{a}$ & 0,52 \\
\hline $\mathbf{M g}$ & 0.28 ode & nd. & $0,34 \mathrm{bcd}$ & $0,60 \mathrm{a}$ & $0,24 \mathrm{de}$ & $0,36 \mathrm{bc}$ & $0,39 \mathrm{~b}$ & $0,37 \mathrm{bc}$ & 0.41 \\
\hline $\mathbf{S}$ & $0,16 \mathrm{bc}$ & nd. & $0,13 \mathrm{c}$ & $0,16 b c$ & $0,23 a$ & $0,19 b$ & $0,17 b$ & $0,13 c$ & 0,03 \\
\hline $\mathrm{Fe}$ & $933 b$ & n.d. & $1496 a$ & $1188 a b$ & $1480 \mathrm{a}$ & $951 b$ & $1083 b$ & $1000 \mathrm{~b}$ & 366 \\
\hline $\mathrm{Zn}$ & $760 d$ & n.d. & $174 a$ & $144 a b$ & $107 \mathrm{bc}$ & $40 d$ & $103 b c$ & $137 a b$ & 54 \\
\hline B & $31 \mathrm{bc}$ & $39 b$ & $25 \mathrm{~cd}$ & $55 a$ & $43 a b$ & $34 b c$ & $37 b c$ & $13 d$ & 14 \\
\hline Mn & 85 def & n.d. & 109 cde & $265 a$ & $121 \propto d$ & $53 f$ & 81 ef & $124 c$ & 36 \\
\hline $\mathrm{Cu}$ & $82 \mathrm{abc}$ & nd. & 33 ad & 90 ab & $134 a$ & Slbod & 38 bod & $20 \mathrm{~d}$ & 52 \\
\hline
\end{tabular}

A omissão de fósforo da solução nutritiva diminuiu os teores de $\mathrm{P}$ e $\mathrm{Ca}$ nas raizes enquanto os de $\mathrm{Fe}$ e $\mathrm{Zn}$ aumentaram significativamente.

Somente o teor de potássio foi significativamente menor no tratamento sem potássio, que nas raizes das plantas tratadas com solução completa. Os nutrientes $\mathrm{Mg}, \mathrm{Zn}, \mathrm{B}$ e Mn apresentaram maior concentração.

A omissão do cálcio diminuiu somente o teor do nutriente nas raizes enquanto aumentou os teores de $\mathrm{N}, \mathrm{S}, \mathrm{B}, \mathrm{Fe}$ e $\mathrm{Cu}$.

A omissão do ferto fez com que os teores nas raizes de $\mathrm{P}$ e $\mathrm{Ca}$ dimimuissem significativamente quando comparados com os do tratamento completo.

Somente o teor de $\mathrm{Mg}$ das raizes do tratamento sem $\mathrm{Zn}$ foi significativamente maior do que os das raizes do tratamento completo.

A omissão de boro afetou somente os teores de micronutrientes, aumentando significativamente os teores de $\mathrm{Zn}$ e Mn e diminuindo os de $\mathrm{Cu}$ e de B. 


\subsubsection{Planta inteira}

O potássio foi o nutriente que se apresentou em maiores quantidades na planta do tratamento completo $(3,93 \%)$. A Tabela 11 apresenta os teores dos nutrientes analisados em toda a planta em função dos tratamentos que receberam. $\mathrm{Na}$ tabela podese observar que os teores de nutrientes não sofreram tantas variaç̃̃es como quando se analisa os órgãos separadamente. Até mesmo grandes variações, como as das folhas por exemplo, são compensadas pelas outras partes quando se analisa a planta por inteiro.

Tabela 11. Teores médios de nutrientes na planta inteira em função dos tratamentos.

\begin{tabular}{|c|c|c|c|c|c|c|c|c|}
\hline \multirow[b]{2}{*}{ Nutrientes } & \multicolumn{7}{|c|}{ TRATAMENTOS } & \multirow[b]{2}{*}{$\underline{\text { DMS }}^{*}$} \\
\hline & Compleo & $\operatorname{sen} P$ & $\operatorname{sen} K$ & $\operatorname{sen} \mathrm{C}_{3}$ & $\operatorname{sem} F e$ & $\operatorname{sen} 2 n$ & $\operatorname{sen} B$ & \\
\hline $\mathbf{N}$ & $2, \pi 70 d$ & $2,53 \mathrm{~d}$ & $3,66 \mathrm{mb}$ & $4,31 \mathrm{a}$ & 2,91cd & $3,62 \mathrm{ab}$ & 3,06 bed & 0,70 \\
\hline$P$ & $0,37 d$ & $0,14 e$ & $0,46 \mathrm{ab}$ & $0,50 \mathrm{a}$ & $0,38 d$ & 0,40 od & $0,44 \mathrm{bc}$ & 0,05 \\
\hline $\mathbf{K}$ & $3,93 c$ & $3,60 \mathrm{c}$ & $0,49 \mathrm{~d}$ & $5,30 \mathrm{~m}$ & $3,92 c$ & $4,44 b$ & $3,92 c$ & 0,45 \\
\hline $\mathrm{Ca}$ & $1,04 c$ & $0,95 c$ & $1,38 \mathbf{a}$ & $1,01 \mathrm{c}$ & $0,94 c$ & $1,07 b c$ & $1,094 \mathrm{c}$ & 0,16 \\
\hline $\mathrm{Mg}$ & 0,4600 & $0,41 d$ & $0,95 \mathrm{a}$ & $0,42 d$ & $0,520 \mathrm{cc}$ & $0,54 b$ & $0,48 b c d$ & 0,07 \\
\hline $\mathbf{S}$ & $0,16 \mathrm{~b}$ & $0,13 c$ & $0,17 \mathrm{~b}$ & $0,22 \mathrm{a}$ & $0,16 b$ & 0,176 & $0,17 b$ & 0,02 \\
\hline $\mathrm{Fe}$ & $302 c$ & $546 \mathrm{ab}$ & $393 b c$ & 604 & $3996 x$ & $369 c$ & $4358 \mathrm{c}$ & 156 \\
\hline $\mathrm{Zn}$ & $34 \mathrm{ad}$ & $71 \mathrm{a}$ & $59 a b$ & $59 \mathrm{ab}$ & 23d & $40 c$ & $56 \mathrm{~b}$ & 14 \\
\hline B & $41 d$ & 35d & $81 b$ & $99 a$ & $42 d$ & $45 d$ & $38 d$ & 15 \\
\hline $\mathbf{M n}$ & 31 e & $46 \mathrm{~cd}$ & 670 & $157 a$ & $38 d e$ & 38de & $44 a d$ & 13 \\
\hline $\mathrm{Cu}$ & $15 b$ & 140 & 166 & $35 a$ & $12 b$ & Ilb & 106 & 9 \\
\hline
\end{tabular}

As plantas cultivadas na solução sem fósforo apresentaram um aumento significativo nos teores dos nutrientes Fe, Zn e Mn e queda na concentração de S.

As plantas do tratamento sem potássio, que foram significativamente menores e com pequena produção de massa de material verde, foram mais ricas em todos os mutrientes, com excessão do $\mathrm{B}$ e do $\mathrm{K}$, que tiveram teores menores na planta quando considerada por inteira. 
Nas plantas do tratamento sem cálcio, que sofreram um severo ataque bacteriano, ocorreu o mais alto teor de $\mathrm{N}(4,31 \%)$ e de $\mathrm{Fe}(604 \mathrm{ppm})$ de todo o experimento

A omissão de zinco provocou aumento do teor médio de nitrogênio, potássio e magnésio na planta, que foram significativamente superiores que o das plantas do tratamento completo. Os demais nutrientes não apresentaram alterações nas suas concentraçōes.

Os teores de nutrientes nas plantas cultivadas nos tratamentos sem ferto não apresentaram diferenças significativas dos teores encontrados nas plantas do tratamento completo.

\subsection{Quantidade de nutrientes}

\subsubsection{Folhas}

A Tabela 12 apresenta a quantidade de nutrientes contidos nas folhas das plantas em função dos tratamentos que receberam. As folhas armazenaram aproximadamente metade de todos os nutrientes da planta e somente $20 \%$ do $\mathrm{Cu}$. 
Tabela 12. Quantidade de nutrientes nas folhas em função dos tratamentos.

\begin{tabular}{|c|c|c|c|c|c|c|c|c|}
\hline \multirow[b]{2}{*}{ Vutrientes } & \multicolumn{8}{|c|}{ TRATAMENTOS } \\
\hline & Completo & $\operatorname{sem} P$ & $\operatorname{sen} K$ & $\operatorname{sem} \mathrm{Ca}$ & $\operatorname{sen} \mathrm{Fe}$ & $\operatorname{sem} \mathrm{Zn}$ & $\operatorname{sen} B$ & $\underline{\text { DMS* }}$ \\
\hline $\mathbf{N}$ & $467,7 \mathrm{ab}$ & $236,3 \mathrm{de}$ & 272, ocde & $175,1 \mathrm{e}$ & $352,3 \mathrm{bod}$ & $459,9 \mathrm{ab}$ & $401.4 a b c$ & 160.5 \\
\hline $\mathbf{P}$ & $38,6 a$ & $9,9 b$ & $29.5 \mathrm{a}$ & $14,5 b$ & $32,9 a$ & $37,0 \mathrm{a}$ & $33,7 \mathrm{a}$ & 14,7 \\
\hline $\mathbf{K}$ & $444,5 \mathrm{ab}$ & $234,5 \mathrm{~cd}$ & $25.7 \mathrm{e}$ & $202.2 \mathrm{~d}$ & $356,6 \mathrm{bod}$ & $426,1 \mathrm{ab}$ & $354,0 \mathrm{bc}$ & 148.0 \\
\hline $\mathrm{Ca}$ & $156,9 a b$ & $86,8 \propto d$ & $112,7 \mathrm{cc}$ & $49,9 d$ & $118,2 b c$ & $142,7 \mathrm{ab}$ & $118,0 \mathrm{ab}$ & $\$ 4,2$ \\
\hline $\mathrm{Mg}$ & $70.8 \mathrm{a}$ & $39,0 \mathrm{~cd}$ & $75,7 \mathrm{a}$ & $21,1 d$ & 63,5 ab & $73,9 \mathrm{a}$ & $60,2 \mathrm{abc}$ & 21.8 \\
\hline S & $20,1 a$ & $7,2 \mathrm{c}$ & $10,1 b c$ & $7,6 \mathrm{c}$ & $16,9 \mathrm{ab}$ & $21,0 a$ & $18,5 \mathrm{a}$ & 7,4 \\
\hline $\mathrm{Fe}$ & $4560 \mathrm{abc}$ & 2641d & 2914 cd & $2147 e$ & $4540 \mathrm{abc}$ & $5046 \mathrm{ab}$ & 3515 bed & 1772 \\
\hline $\mathrm{Zn}$ & $486 a$ & $3734 a b c$ & $390 \mathrm{abc}$ & $192 \mathrm{c}$ & $252 b c$ & $477 a$ & $412 a b$ & 201 \\
\hline B & $592 \mathrm{~b}$ & $395 b$ & $754 a b$ & $671 b$ & $536 \mathrm{~b}$ & $679 b$ & $584 b$ & 374 \\
\hline $\mathrm{Mn}$ & $543 a b$ & $271 \mathrm{c}$ & $448 b c$ & $435 b c$ & $\$ 66 a b$ & $582 a b$ & $344 b c$ & 245 \\
\hline $\mathrm{Cu}$ & $90 \mathrm{abc}$ & $58 \mathrm{~cd}$ & $64 \mathrm{~cd}$ & $46 d$ & 64bod & $100 \mathrm{ab}$ & $76 \mathrm{abcd}$ & 396 \\
\hline
\end{tabular}

Macronutrientes expressos em mg.

Micronutrientes expressos em $\mu \mathrm{g}$.

- DMS = Diferenca Minima Sigmificativa.

Obs.: Números seguidos da mesma letra nas linhas não diferem significativamente pelo teste de Tukey a $5 \%$.

Por falta de material, não foi possivel a realização das análises químicas das folhas das plantas tratadas sem $\mathrm{N}$ e, conseqüentemente, a determinação da sua quantidade de nutrientes.

A omissão de fósforo da solução nutritiva reduziu significativamente a quantidade de todos os nutrientes contidos nas folhas, com excessão do $\mathrm{Zn}, \mathrm{Cu}$ e $\mathrm{Mn}$, mostrando a importância do nutriente na nutrição da planta.

Essa diminuição de extração não foi só em função da menor massa seca produzida pelas plantas, como nos casos do $\mathrm{K}$, Ca e $\mathrm{P}$, mas também em função da menor concentração de $\mathrm{P}$ e Fe.

A omissão do potássio reduziu o acúmulo dos macronutrientes nas folhas, excluindo o Mg. Conforme foi observado por SINHA \& SINGH (1984), a alta concentração nas folhas é alcançada com uma pequena quantidade de nutrientes, pela pequena produção de massa de material seca e reduzida área foliar. Os micronutrientes já não foram tão afetados neste tratamento. 
O tratamento sem cálcio foi o que mais diminuiu a quantidade de nutrientes nas folhas em relação ao tratamento completo. De todos os nutrientes somente o B e Mn não diferiram significativamente.

Deve-se considerar no entanto, $O$ ataque bacteriano que as plantas desse tratamento sofreram, o que reduziu muito a quantidade de massa de material seco de folhas. Neste caso a quantidade de $\mathrm{N}$ nas folhas foi muito reduzida, embora sua concentração tenha sido bastante elevada.

A omissão de ferro não afetou a quantidade de nutrientes nas folhas, mas diminuiu significativamente a quantidade de $\mathrm{Ca}$ e $\mathrm{Zn}$ extraidos.

A omissão de boro diminuiu significativamente somente a quantidade desse nutriente nas folhas não se constatou a observação de FISHER \& BUCHHOLZ (1985), que preconizaram uma menor quantidade de Ca nas plantas cultivadas com pouco B.

A omissão de zinco não afetou significativamente a quantidade de todos os nutriente analisados.

\subsubsection{Hastes}

A Tabela 13 mostra as quantidades de nutrientes contidos nas hastes das plantas em função dos tratamentos que receberam. No tratamento com solução completa esse órgão continha entre $9 \%$ do $\mathrm{Cu}$ e $18 \%$ do $\mathrm{Ca}$ e $\mathrm{Mg}$ da planta inteira. 
Tabela 13. Quantidade de nutrientes nas hastes em função dos tratamentos.

\begin{tabular}{|c|c|c|c|c|c|c|c|c|c|}
\hline \multirow[b]{2}{*}{ Vutrientes } & \multicolumn{8}{|c|}{ TRATAMENTOS } & \multirow[b]{2}{*}{$\underline{\mathrm{DMS}^{*}}$} \\
\hline & Completo & $\operatorname{sen} N$ & $\operatorname{sen} P$ & $\operatorname{sen} K$ & $\operatorname{sem} C a$ & $\operatorname{sen} \mathrm{Fe}$ & $\operatorname{sem} \mathrm{Zn}$ & $\operatorname{sen} B$ & \\
\hline $\mathbf{N}$ & $139.0 \mathrm{ab}$ & $4,4 b$ & $45,7 \mathrm{~b}$ & $40,6 b$ & $101,8 b$ & 83,70 & $276,8 \mathrm{a}$ & $77.0 \mathrm{~b}$ & 170,0 \\
\hline $\mathrm{P}$ & $20,8 \mathrm{a}$ & nd. & $2,8 \mathrm{~b}$ & $5,3 b$ & $10.2 \mathrm{ab}$ & $13,3 \mathrm{ab}$ & $22,2 \mathrm{a}$ & $11,2 \mathrm{ab}$ & 13.9 \\
\hline K & $261,7 a b$ & nd. & 71,0 od & $4,0 \mathrm{~d}$ & $126,5 \mathrm{bod}$ & $152,1 \mathrm{abod}$ & $303.3 a$ & $147,7 \mathrm{abcod}$ & 171.0 \\
\hline $\mathrm{Ca}$ & $62,4 a$ & nd. & $24,1 \mathrm{bc}$ & $10,0 c$ & $17,5 \mathrm{c}$ & 33, labc & $51,6 a b$ & $25,7 b c$ & 32,3 \\
\hline $\mathrm{Mg}$ & $26,9 a b$ & nd. & $8,9 c$ & $12,8 \mathrm{bc}$ & $6,9 c$ & 18.5abc & $32,6 a$ & $13,6 b c$ & 16,5 \\
\hline $\mathrm{S}$ & $8.2 \mathrm{ab}$ & nd. & $3,3 \mathbf{a b}$ & $2,2 b$ & $4,9 \mathrm{ab}$ & $6,0 \mathrm{ab}$ & $8,7 a$ & $4,8 \mathrm{ab}$ & 6,0 \\
\hline $\mathrm{Fe}$ & $624 a b$ & nd. & $209 \mathrm{c}$ & $234 \mathrm{bc}$ & $294 \mathrm{bc}$ & $348 b c$ & $824 a$ & $296 \mathrm{bc}$ & 399 \\
\hline $\mathrm{Zn}$ & $180 \mathrm{a}$ & nd. & $70 b$ & $70 b$ & $63 \mathrm{~b}$ & $54 b$ & $143 a b$ & $80 b$ & 94 \\
\hline B & $235 \mathrm{a}$ & $30,4 c$ & $54 \mathrm{bc}$ & $49 b c$ & $47 b c$ & $102 \mathrm{bc}$ & $153 a b$ & $52 \mathrm{bc}$ & 119 \\
\hline $\mathbf{M n}$ & $124 b$ & nd. & $70 b$ & $56 b$ & $615 a$ & $82 b$ & $155 \mathrm{~b}$ & $81 b$ & 303 \\
\hline $\mathrm{Cu}$ & $43 \mathbf{a}$ & n.d. & $19 b$ & $10 b$ & $14 b$ & $16 b$ & $33 a b$ & $11 \mathbf{b}$ & 23 \\
\hline
\end{tabular}

Além da menor concentração no tratamento sem nitrogênio, a baixa produção de massa de material seco de hastes das plantas desse tratamento, fez com que a quantidade de $B$ nesse órgão fosse significativamente menor (8 vezes) do que nas plantas do tratamento completo. Apesar da quantidade de $\mathrm{N}$ nas hastes ter sido 35 vezes menor, não se observou diferença significativa devido ao alto coeficiente de variação.

O efeito da omissão de fósforo foi muito grande na produção de massa de material seco, o que fez com que o $\mathrm{P}, \mathrm{K}, \mathrm{Ca}, \mathrm{Mg}, \mathrm{Fe}, \mathrm{Zn}, \mathrm{B}$ e $\mathrm{Cu}$, fossem acumulados em quantidades significativamente menores nas hastes, semelhantes aos encontrados por SINGH \& SINGH (1968a).

Assim como nos tratamentos sem fósforo e sem nitrogênio, a omissão de potássio fez com que a quantidade de matérial seco de hastes fosse pequena, diminuindo significativamente a quantidade dos nutrientes $\mathrm{P}, \mathrm{K}, \mathrm{Ca}, \mathrm{Zn}, \mathrm{B}$ e $\mathrm{Cu}$ contidos nas hastes em relação às plantas do tratamento completo. 
A menor produção de massa de material seco do tratamento sem cálcio foi responsável pela menor quantidade de $\mathrm{Ca}, \mathrm{Mg}, \mathrm{Zn}, \mathrm{B}$ e $\mathrm{Cu}$ contida nas hastes, porém ocorreu um significativo aumento na quantidade de Mn nesses tecidos em função da sua alta concentração.

A omissão de Fe na solução nutritiva não afetou significativamente nem a produção de massa de material seco das hastes, nem os teores de nutrientes, porém a quantidade de $\mathrm{Zn}, \mathrm{B}$ e $\mathrm{Cu}$ foram significativamente menores nas hastes desse tratamento do que no tratamento completo.

No tratamento sem boro as quantidades de $\mathrm{Ca}, \mathrm{Zn}, \mathrm{Cu}$ e do próprio $\mathrm{B}$, foram significativamente menores que as das hastes das plantas cultivadas com solução nutritiva completa. Segundo FISHER \& BUCHHOLZ (1985), a menor quantidade de Ca estaria relacionada com a má formação de parede celular.

Não observou-se diferença significativa entre nenhum dos nutrientes analisados no tratamento sem $\mathrm{Zn}$.

\subsubsection{Estoloes}

As quantidades de nutrientes nos estolões da planta mostram que esse órgão é um importante armazenador de nutrientes. Enquanto seu peso em relação à planta inteira atinge cerca de $30 \%$, alguns nutrientes alcançam uma relação ainda maior. Cerca de $35 \%$ do $\mathrm{K}$ e do $\mathrm{S}$, por exemplo, encontra-se nos estolð̃es. A Tabela 14 apresenta as quantidades de nutrientes presentes nesse órgão em função do tratamento que receberam. 
Tabela 14. Quantidade de nutrientes nos estolões em função dos tratamentos.

\begin{tabular}{|c|c|c|c|c|c|c|c|c|c|}
\hline \multirow[b]{2}{*}{ Vutrientes } & \multicolumn{8}{|c|}{ TRAT AMENTOS } & \multirow[b]{2}{*}{$\underline{\mathrm{DMS}}{ }^{*}$} \\
\hline & Completo & $\operatorname{sem} N$ & $\operatorname{sen} P$ & $\operatorname{sen} K$ & $\operatorname{sen} \mathrm{Ca}$ & $\operatorname{sen} \mathrm{Fe}$ & $\operatorname{sen} Z n$ & $\operatorname{sen} B$ & \\
\hline $\mathbf{N}$ & $223.6 \mathrm{a}$ & $6,7 \mathrm{c}$ & $123,8 \mathrm{abc}$ & $103,9 \mathrm{abc}$ & $63 \mathrm{bc}$ & $180,6 \mathrm{ab}$ & $178,6 a b$ & $140,1 \mathrm{ab}$ & 121,7 \\
\hline $\mathrm{P}$ & $34.8 \mathrm{a}$ & $2.5 \mathrm{~d}$ & $9,3 \mathrm{~cd}$ & $13,3 \mathrm{bod}$ & $8,8 \propto d$ & $29,1 \mathbf{a b}$ & $29,5 a b$ & $25,2 \mathrm{abc}$ & 18.3 \\
\hline $\mathbf{K}$ & $440,0 \mathrm{a}$ & $18,5 b$ & $219,4 a b$ & $24,8 b$ & $80,5 b$ & $338,4 a$ & $350,1 \mathrm{a}$ & $238,9 \mathrm{ab}$ & 241,1 \\
\hline $\mathrm{Ca}$ & $51,3 a b$ & $3,7 \mathrm{c}$ & $24,5 a b c$ & $23,9 \mathbf{b c}$ & $13,7 \mathrm{c}$ & $36,6 a b c$ & $38,1 \mathrm{abc}$ & $29,4 a b c$ & 37,5 \\
\hline $\mathrm{Mg}$ & $39,1 a$ & $1,4 \mathrm{c}$ & $18,2 \mathrm{bc}$ & $18,4 \mathrm{bc}$ & 5,60 & $30,1 \mathrm{ab}$ & $29,4 a b$ & $19,3 a b c$ & 20,4 \\
\hline $\mathbf{S}$ & $15,9 \mathrm{a}$ & $0,8 d$ & $9,2 \mathrm{abc}$ & $6,0 \mathrm{bcd}$ & $3,6 \mathrm{~cd}$ & $9,7 \mathrm{abc}$ & $10,5 a b c$ & $9,1 a b c$ & 8,1 \\
\hline $\mathrm{Fe}$ & $1072 \mathrm{abc}$ & $114 c$ & $748 a b c$ & $451 b c$ & $293 b c$ & $671 b c$ & $947 a b c$ & $1686 a$ & 963 \\
\hline $\mathrm{Zn}$ & $184 a b c$ & $37 c$ & $144 a b c$ & $110 \mathrm{abc}$ & $75 \mathrm{bc}$ & $90 \mathrm{abc}$ & $186 \mathrm{abc}$ & $246 a$ & 157 \\
\hline B & $369 a$ & $19 \mathrm{c}$ & $124 a b c$ & $102 \mathrm{bc}$ & $75 \mathrm{bc}$ & $241 a b c$ & $276 \mathrm{abc}$ & $174 a b c$ & 267 \\
\hline Mn & $31 a b$ & $10 b$ & $46 a b$ & $57 \mathrm{ab}$ & $147 \mathrm{a}$ & $58 a b$ & $35 \mathrm{ab}$ & $84 a b$ & 120 \\
\hline $\mathrm{Cu}$ & $61 a$ & $4 c$ & $39 \mathrm{ab}$ & $31 a b c$ & $15 \mathrm{bc}$ & 29abc & $45 a b$ & $52 a$ & 33 \\
\hline
\end{tabular}

A omissão de nitrogênio na solução nutritiva ocasionou uma diminuição drástica na produção de matérial seco de estolōes, resultando numa redução significativa na quantidade de todos os macronutrientes. Já os micronutrientes, apesar de ocorrerem em menor quantidade, não apresentaram diferenças significativas em relação ao tratamento completo, exceto $\mathrm{B}$ e $\mathrm{Cu}$, devido ao alto coeficiente de variação obtido.

Com exceção do próprio fósforo e do magnésio, nenhum outro nutriente ocorreu em quantidades significativamente menores do que aquelas encontradas nos estolōes das plantas cultivadas em solução nutritiva completa em relação aos estolões das plantas cultivadas sem fósforo.

O tratamento sem potássio produziu estolões com quantidades menores de $\mathrm{P}, \mathrm{Mg}, \mathrm{S}, \mathrm{B}$ e do próprio $\mathrm{K}$ em relação ao tratamento completo, principalmente, pela pouca massa de material seco produzida. 
Como nos tratamentos sem nitrogênio e sem potássio, os estolões do tratamento sem cálcio acumularam quantidades bem menores de todos os macronutrientes, $\mathrm{B}$ e $\mathrm{Cu}$, devido à baixa produção de massa de material verde.

A omissão de ferro, zinco e boro, não causou nenhuma diferença significativa na quantidade de nutrientes contidos nos estolões.

\subsubsection{Raizes}

A Tabela 15 apresenta os resultados da quantidade de nutrientes nas raizes das plantas em função dos tratamentos que receberam. Por ser uma planta com sistema radicular pouco desenvolvido, a quantidade de nutrientes contido nelas é pequena.

Tabela 15. Quantidade de nutrientes nas raizes.

\begin{tabular}{|c|c|c|c|c|c|c|c|c|c|}
\hline \multirow[b]{2}{*}{ Nutrient } & \multicolumn{8}{|c|}{ TRATAMENTOS } & \multirow[b]{2}{*}{$\underline{\mathrm{DMS}}$} \\
\hline & Comoleto & $\operatorname{sen} N$ & $\operatorname{sen} P$ & $\operatorname{sen} K$ & semca & $\operatorname{senFe}$ & $\operatorname{sen} Z n$ & $\operatorname{sen} B$ & \\
\hline$\frac{\mathrm{e}}{\mathrm{N}}$ & $57,6 a b c$ & $6,2 c$ & 98,52 & $19,1 b c$ & $52,1 a b c$ & $75,6 a b$ & $60,3 \mathrm{abc}$ & $76,5 a b$ & 59,4 \\
\hline $\mathbf{P}$ & $23,2 b$ & n.d. & $5,3 \mathrm{c}$ & $6,7 \mathrm{c}$ & $12,3 \mathrm{bc}$ & $16,9 a b c$ & $20,1 \mathrm{abc}$ & $30,8 \mathbf{a}$ & 15,1 \\
\hline $\mathrm{K}$ & $112,3 \mathrm{ab}$ & n.d. & $187,8 \mathrm{n}$ & $3,4 c$ & $69,0 \mathrm{bc}$ & $137,0 a b$ & $125,2 a b$ & $151,2 \mathrm{ab}$ & 105,1 \\
\hline $\mathrm{Ca}$ & $63,4 a$ & n.d. & $54,6 \mathrm{ab}$ & $17,9 b c$ & $9,6 c$ & $41,1 \mathrm{abc}$ & $55,3 a b$ & $71,5 \mathrm{a}$ & 42,8 \\
\hline $\mathrm{Mg}$ & $9,5 \mathrm{ab}$ & n.d. & $15,9 \mathrm{a}$ & $5,4 \mathrm{~b}$ & $4,3 b$ & $15,0 \mathrm{a}$ & $11,1 \mathrm{ab}$ & $14,8 \mathrm{a}$ & 9,2 \\
\hline $\mathrm{S}$ & $5,8 a b$ & nd & 6,5ab & $1,4 b$ & $4,1 a b$ & 8,1a & $5,0 a b$ & $5,4 a b$ & 5,8 \\
\hline $\mathrm{Fe}$ & 3422ab & nd & $7818 \mathrm{a}$ & 10608 & $2668 b$ & $4303 \mathrm{ab}$ & $3216 a b$ & $4142 a b$ & 4760 \\
\hline$Z \mathbf{n}$ & $254 \mathrm{bc}$ & nd & 828 & $129 c$ & $193 \mathrm{c}$ & $147 \mathrm{c}$ & $292 b c$ & $522 a b$ & 310 \\
\hline B & $106 \mathrm{ab}$ & $22 b$ & $124 a$ & $49 a b$ & $77 a b$ & 136 & $107 a b$ & $53 a b$ & 92 \\
\hline Mn & $308 a b c$ & nd & $517 \mathrm{a}$ & $237 b c$ & $218 b \mathrm{c}$ & $199 \mathrm{c}$ & $233 b c$ & $486 \mathrm{ab}$ & 270 \\
\hline $\mathrm{Cu}$ & $279 a$ & nd & $154 a b c$ & $80 \mathrm{bc}$ & $242 a b$ & $155 \mathrm{abc}$ & $134 \mathrm{abc}$ & $81 b c$ & 195 \\
\hline
\end{tabular}


Devido à pequena quantidade de raizes produzidas pelas plantas do tratamento sem nitrogênio, foi possivel apenas a análise do $\mathrm{N}$ e do $\mathrm{B}$ desses tecidos. Esses dois nutrientes ocorreram em menor quantidade devido à pequena massa de material seco produzido, mas não houve diferença estatística quanto às suas quantidades em relação às plantas do tratamento completo.

A quantidade de nutrientes contida nas raizes das plantas do tratamento sem fósforo não apresentaram diferença estatisticamente significativa em relação ao tratamento completo, exceto $\mathrm{P}$, que foi menor e $\mathrm{Zn}$, que foi maior. Apesar da baixa concentração de $\mathrm{Ca}$ e $\mathrm{Cu}$ nesses órgão, a maior produção de massa de material seco compensou a diferença.

A omissão de potássio na solução nutritiva causou uma queda significativa na quantidade de $\mathrm{P}, \mathrm{Ca}$ e $\mathrm{Cu}$, além do próprio $\mathrm{K}$. Porém esta queda deveuse mais à pequena produção de massa de material seco de raizes, que foi três vezes menor do que no tratamento completo, e não à concentração de nutrientes, que foi semelhante.

No tratamento sem cálcio, somente a quantidade do próprio cálcio nas raizes apresentou uma diferença estatisticamente significativa. Todos os demais nutrientes ocorreram em quantidades semelhantes ao do tratamento completo.

A omissão de ferro e de $\mathrm{Zn}$ não afetou a quantidade dos nutrientes presentes nas raizes.

As raizes cultivadas com solução nutritiva sem boro apresentaram quantidade de $\mathrm{P}$ significativamente maior e $\mathrm{Cu}$ menor do que as raizes das plantas do tratamento completo. 


\subsubsection{Planta inteira}

A Tabela 16 apresenta as quantidades médias de nutrientes contidas nas plantas de cada vaso em função dos tratamentos que receberam. $O K$ foi o nutriente extraido em maior quantidade pelas plantas, sendo seguido pelo $\mathrm{N}, \mathrm{Ca}, \mathrm{Mg}, \mathrm{P}$ e $\mathrm{S}$. Entre os micronutrientes, o Fe foi o mais extraido, seguido pelo $\mathrm{B}, \mathrm{Zn}, \mathrm{Mn}$ e $\mathrm{Cu}$.

Tabela 17. Quantidade de nutrientes na planta inteira.

\begin{tabular}{|c|c|c|c|c|c|c|c|c|}
\hline \multirow[b]{2}{*}{ Nutrientes } & \multicolumn{8}{|c|}{ TRATAMENTOS } \\
\hline & Compleso & $\operatorname{sem} P$ & $\operatorname{sen} K$ & $\operatorname{sem} C_{a}$ & $\operatorname{sen} F e$ & $\operatorname{sen} 2 n$ & $\mathrm{~B}^{\operatorname{sem}}$ & $\underline{\text { DMS* }}$ \\
\hline$N$ & $887,9 a$ & $504,4 b c$ & $435,7 \mathrm{c}$ & $391,9 c$ & $692,3 a b c$ & 975,62 & $694,9 a b c$ & 382,6 \\
\hline $\mathbf{P}$ & $117,3 \mathbf{a}$ & $27,3 \mathrm{c}$ & $54,7 \mathrm{bc}$ & $45,8 \mathrm{c}$ & $92,1 a b$ & $108,8 \mathrm{a}$ & $100,9 a$ & 44,9 \\
\hline $\mathbf{K}$ & $1258,5 \mathrm{a}$ & $713,2 \mathrm{bc}$ & $57,9 d$ & $478,6 \mathrm{~cd}$ & $964,2 \mathrm{abc}$ & $1204,8 a b$ & $891,8 a b c$ & 500,3 \\
\hline $\mathrm{Ca}$ & $334,1 \mathrm{a}$ & 189,9 bcd & $164,5 \mathrm{~cd}$ & $90,7 d$ & $229,0 \mathrm{abc}$ & $287,8=a b$ & $244,6 \mathrm{abc}$ & 117,1 \\
\hline $\mathbf{M g}$ & $146,3 \approx$ & $82,0 \mathrm{cc}$ & $112,4 a b$ & $38,0 c$ & $127,0 \mathrm{ab}$ & $147,1 \mathrm{a}$ & $107,9 \mathrm{mb}$ & 55,3 \\
\hline S & $49,9 \mathrm{a}$ & $26,1 b c$ & $19,7 \mathrm{c}$ & $20,2 \mathrm{c}$ & $40,7 \mathrm{abc}$ & $45,2 \mathrm{ab}$ & $37,8 \mathrm{abc}$ & 21,0 \\
\hline $\mathrm{Fe}$ & $9678 \mathrm{ab}$ & $11416 a$ & 46600 & $5402 a b$ & $9861 \mathrm{ab}$ & $10033 a b$ & $9639 a b$ & 6385 \\
\hline $\mathrm{Zn}$ & $1104 a b c$ & $1416 a$ & $698 \mathrm{Bc}$ & $523 c$ & $543 c$ & $1098 a b c$ & $1260 \mathrm{ab}$ & 587 \\
\hline $\mathbf{B}$ & $1303 \mathrm{ab}$ & 6970 & $954 b$ & 8706 & $1015 \mathrm{ab}$ & $1215 \mathrm{ab}$ & $864 \mathrm{~b}$ & 625 \\
\hline $\mathbf{M n}$ & $1006 \mathrm{a}$ & $903 a$ & $797 \mathrm{a}$ & 1416 & $905 a$ & $1007 a$ & $994 \pi$ & 751 \\
\hline $\mathrm{Cu}$ & $473 a$ & $269 \mathrm{ab}$ & $185 \mathrm{~b}$ & $317 a b$ & $264 a b$ & $312 \mathrm{ab}$ & $219 \mathrm{~b}$ & 239 \\
\hline
\end{tabular}

Devido à pequena quantidade de material vegetal produzido no tratamento sem nitrogênio, não foi possivel a determinação dos teores de nutrientes e o cálculo das quantidades extraídas pela planta.

Nas plantas tratadas com solução nutritivas sem fósforo, houve um decréscimo significativo nas quantidades extraidas de todos os macronutrientes. Deve-se notar porém, que a ausência de fósforo na solução nutritiva causou uma menor extração 
de todos os macronutrientes, mas não diferiram significativamente do tratamento completo devido ao alto coeficiente de variação do experimento.

O K mostrou-se importante não só por ser o nutriente mais extraido pela planta, mas também pela sua influência na absorção de outros nutrientes. Sua omissão na solução causou uma significativa queda na quantidade absorvida de $\mathrm{N}, \mathrm{P}, \mathrm{Ca}, \mathrm{S}, \mathrm{Cu}$ e do próprio $K$, resultando em baixa produção de massa de material seco.

Devido ao ataque bacteriano não foi possivel creditar os efeitos observados no tratamento sem cálcio somente à omissão do nutriente. Porém os efeitos foram bastante significativos, sendo este o único tratamento do experimento em que a quantidade de $\mathrm{N}$ foi superior à de $\mathrm{K}$, havendo decréscimo nas quantidades extraidas de todos os macronutrientes e de $\mathrm{Zn}$.

A omissão de ferro, zinco e do boro das soluçðes nutritiva não afetaram significativamente a extração de nenhum dos nutrientes analisados.

\subsection{Doença bacteriana}

As plantas que se desenvolveram em solução nutritiva sem cálcio, apresentaram encharcamento e amarelecimento dos tecidos das folhas, progredindo para manchas necróticas pardas, com posterior queda.

A inoculação artificial, por pulverização em folhas de plantas sadias, reproduziu a doença, confirmando a sua patogenicidade segundo os postulados de Koch.

Através de análises microbiológicas, verificou-se que se tratava de bactéria móvel, bastonetiforme, Gram negativa, oxidativa, catalase positiva, segundo as 
metodologias de LELLIOT \& STEAD (1987) e SCHAAD (1988), sendo caracterizadas no gênero Pseudomonas.

\subsection{Qualidade do óleo essencial}

A omissão dos nutrientes afetou significativamente a composição do óleo essencial da menta e conseqüentemente sua qualidade. Apesar do elevado coeficiente de variação obtido $(50,59 \%)$, devido a diversas variáveis incontroláveis na extração e análise do óleo, quando se comparou o número de substâncias detectadas pela cromatografia, o tratamento que recebeu solução nutritiva completa diferiu estatisticamente dos demais, conforme mostra a Figura 14.

Estudos mais detalhados e com maior volume de plantas cultivadas, com melhores técnicas de extração, e que permitam um controle maior, talvez possam diferenciar sobre a quantidade de substâncias presentes no óleo essencial.

Devido ao elevado coeficiente de variação, não foi possível detectar a importância relativa entre os nutrientes omitidos, uma vez que foram igualadas as médias de 5 e 7 picos dos tratamentos sem nitrogênio e sem potássio, com os 29 picos do tratamento sem magnésio. 


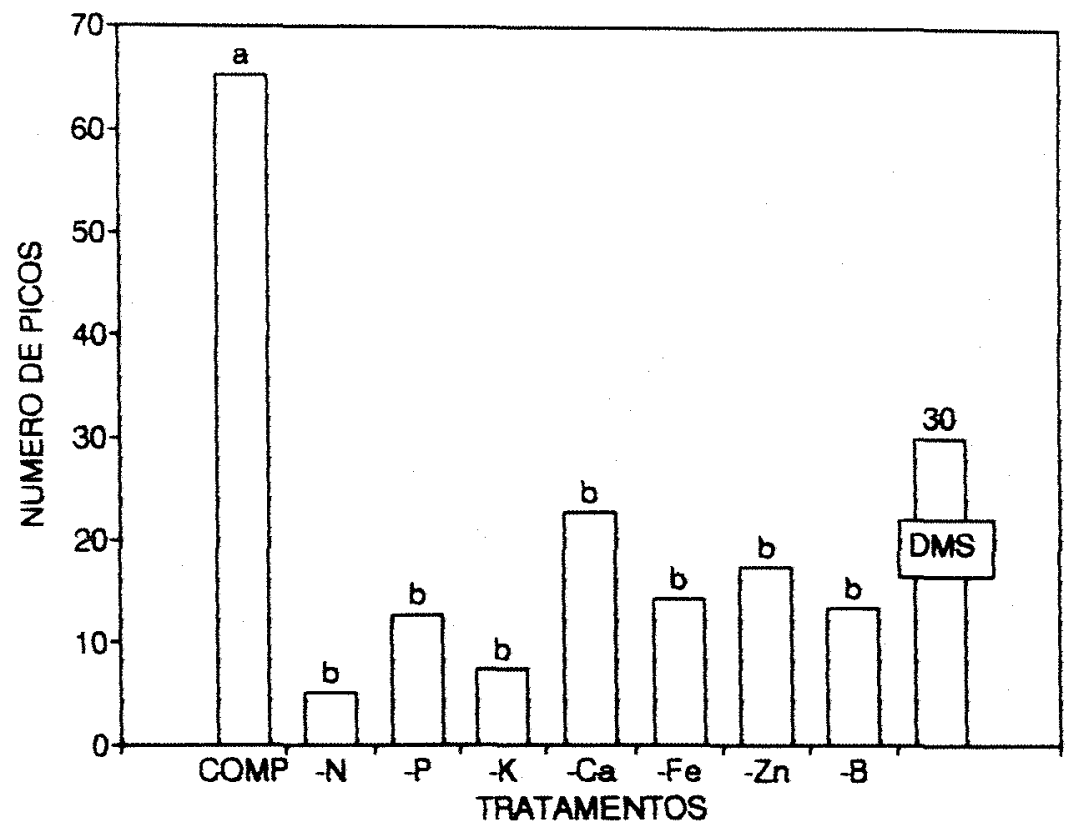

Figura 9. Número de picos cromatográficos obtidos nas análises de óleo essencial das folhas de menta cultivadas com solução nutritiva completa e com omissão de nutrientes. Barras sob letras iguais não diferem significativamente pelo teste de Tuckey a 5\%. DMS = Diferença Minima Significativa .

A Figura 10 mostra os cromatogramas típicos de cada um dos tratamentos. As diferenças entre os picos representam as diferenças entre as composições do óleo essencial de cada tratamento.

Apesar da grande variação observada na cromatografia, para facilidade de análise, serão analisados somente as variações dos teores de limoneno, mentona, mentol e metil acetato. 


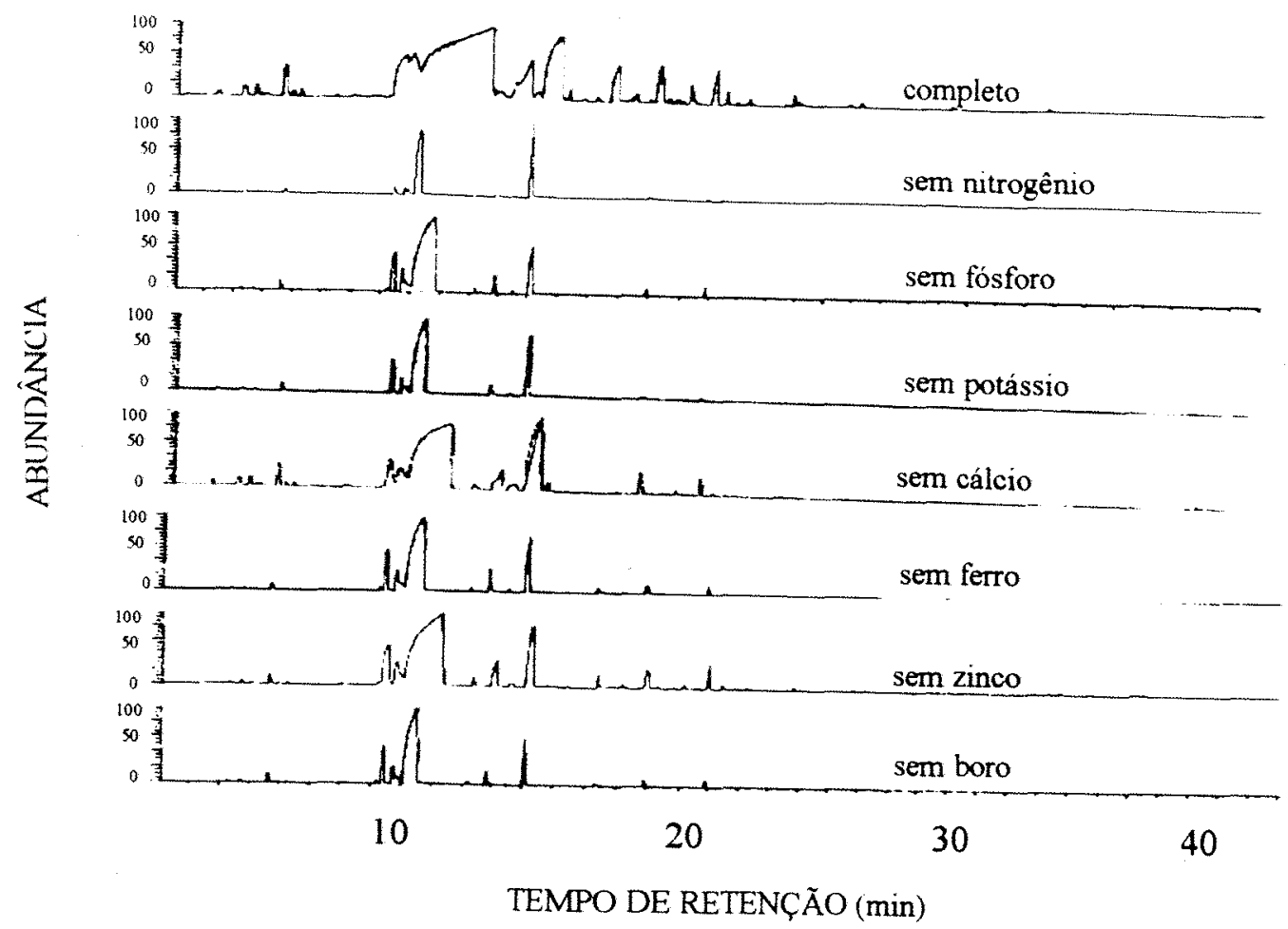

Figura 10. Cromatogramas obtidos nas análises do óleo essencial das folhas de menta cultivadas com solução nutritiva completa e com omissão de nutrientes.

$\mathrm{Na}$ espectrometria de massa do cromatograma do óleo do tratamento completo, os picos com tempo de retenção de $6,649 \mathrm{~min}, 10,498 \mathrm{~min}, 11,777 \mathrm{~min}$ e 15,382 min, foram determinados como limoneno, mentona, mentol e metil acetato, respectivamente. A Figura 11 mostra a espectrometria obtida dessas substâncias no cromatograma do tratamento completo da Figura 10. 


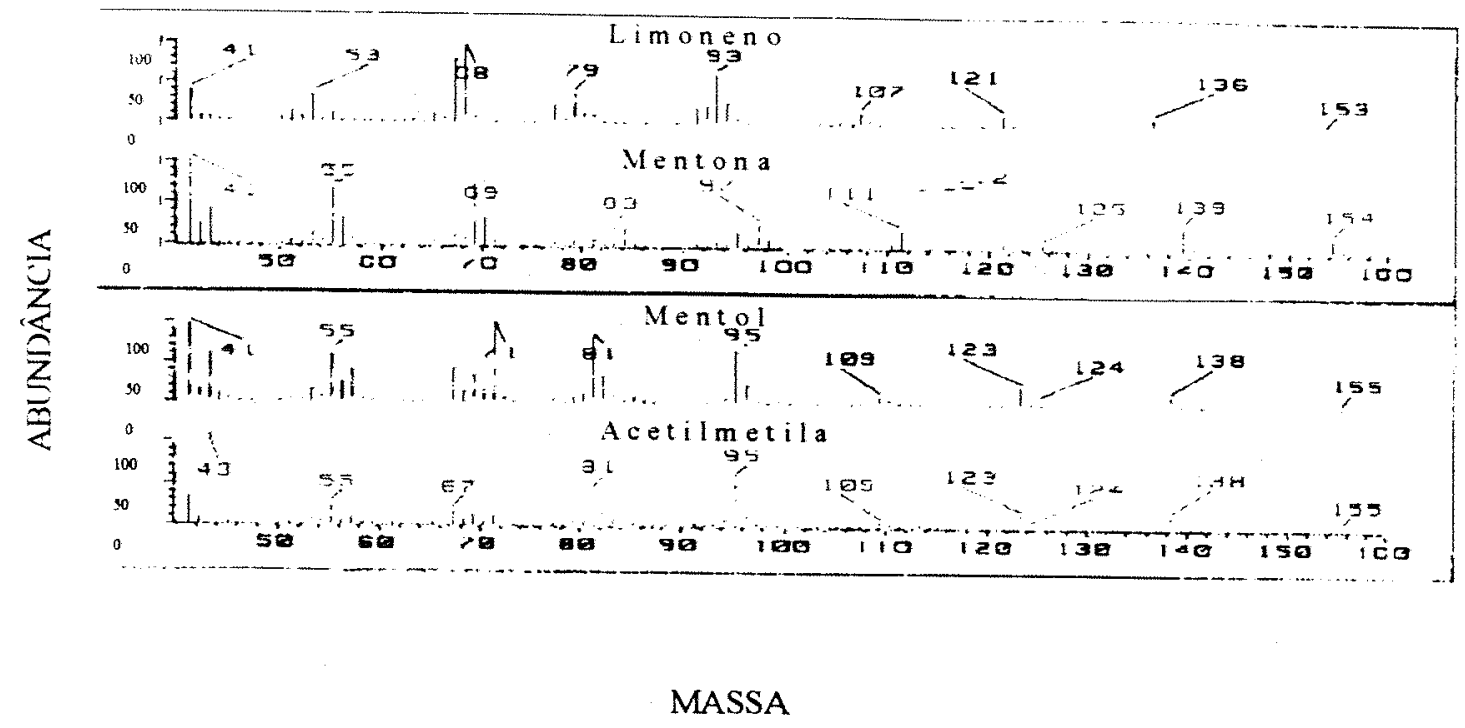

Figura 11. Espectrometria de massa dos picos relativos às substâncias limoneno, mentona, mentol e metil acetato.

\subsubsection{Análise multidimensional}

Os picos cromatográficos representam as substâncias que a coluna do aparelho foi capaz de separar. Isômeros de uma mesma substância geram picos diferentes, mas não alteram necessariamente a qualidade do óleo. Por isso para as análises multidimensionais os isômeros foram integrados e analisados como uma substância única.

As Figuras 12 e 13 , seguiram metodologia de CANTAGREL \& LABLAMQUIE (1986) e indicam, pelo afastamento e agregamento das substâncias em 
relação às concentrações das substâncias, que o fornecimento de solução completa às plantas, proporcionou um óleo com teores mais altos de limoneno e mentona e mais baixos em mentol e metil acetato.

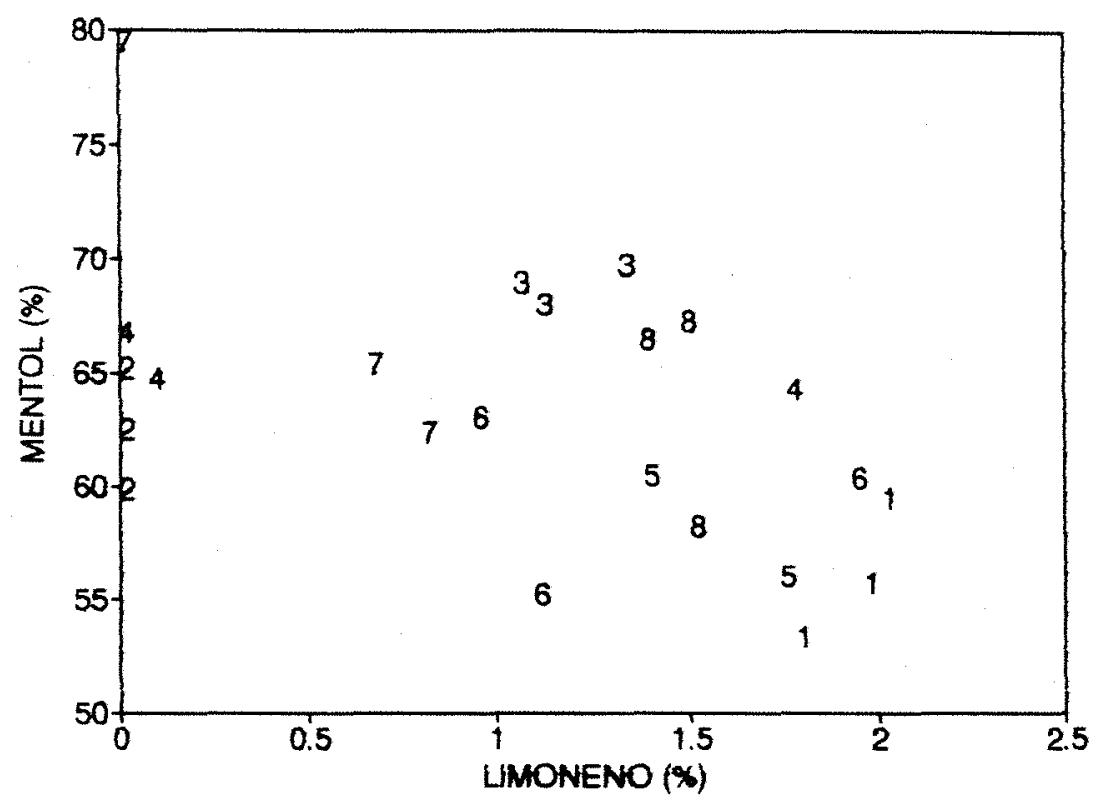

Figura 12. Dispersão das concentrações de limoneno e mentol nos óleos em função da omissão de nutrientes. Os números indicam as soluções utilizadas: $1=$ completa; $2=$ sem nitrogênio; $3=$ sem fósforo; $4=$ sem potássio; $5=$ sem cálcio; $6=\operatorname{sem}$ ferro; $7=$ sem zinco e $8=$ sem boro. 


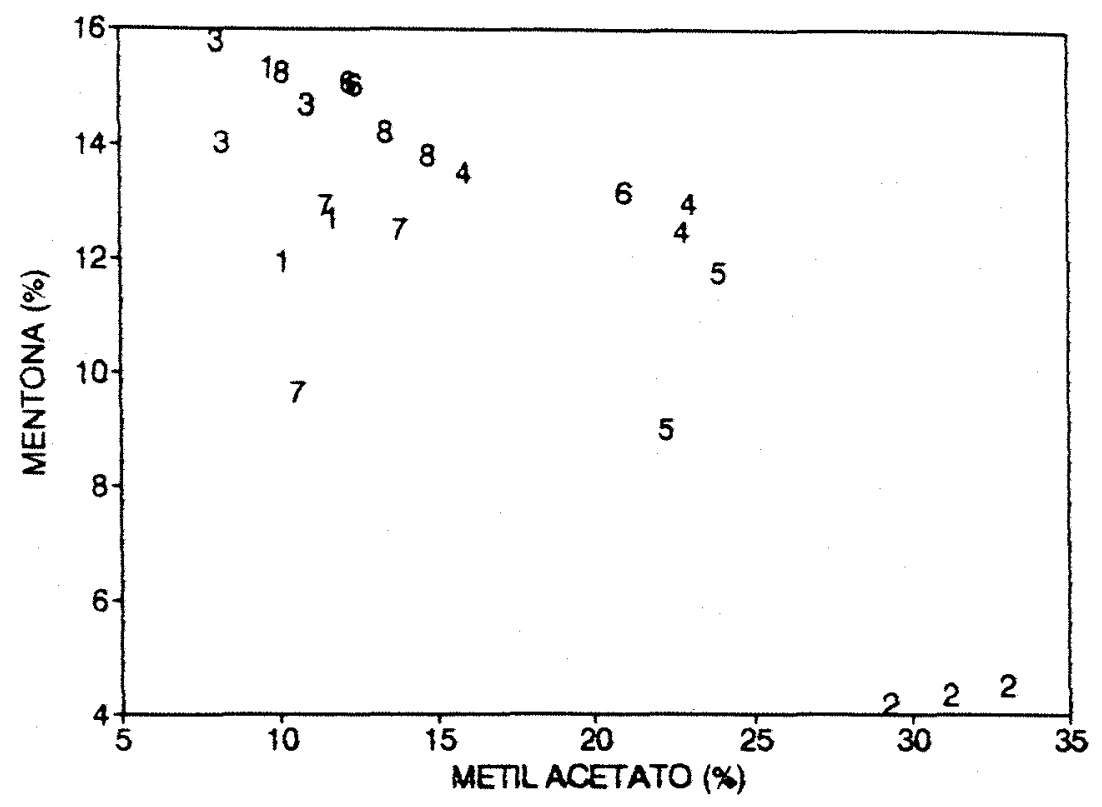

Figura 13. Dispersão das concentrações de mentona e metil acetato nos óleos em função da omissão de nutrientes. Os nümeros indicam as soluções utilizadas: $1=$ completa; 2 = sem nitrogênio; $3=$ sem fósforo; $4=$ sem potássio; $5=$ sem cálcio; 6 = sem ferro; $7=$ sem zinco e $8=$ sem boro.

A omissão dos nutrientes, principalmente do nitrogênio (Figura 10), foi o que mais afetou a qualidade do óleo e teve diferentes efeitos sobre as quatro substâncias, aumentando os teores de mentol e metil acetato e diminuindo os de limoneno e mentona. 


\subsubsection{Limoneno}

A espectrometria de massa do pico cromatográfico com tempo de retenção de 6,649 min, apresentada na Figura 11 determinou que a substância é o limoneno.

O nitrogênio foi o nutriente cuja omissão afetou mais o limoneno, eliminando-o completamente do óleo essencial. Outros nutrientes também tiveram um efeito significativo, conforme pode ser observado na Figura 14, assim, a omissão do zinco e do potássio também diminuiram o teor de Limoneno.

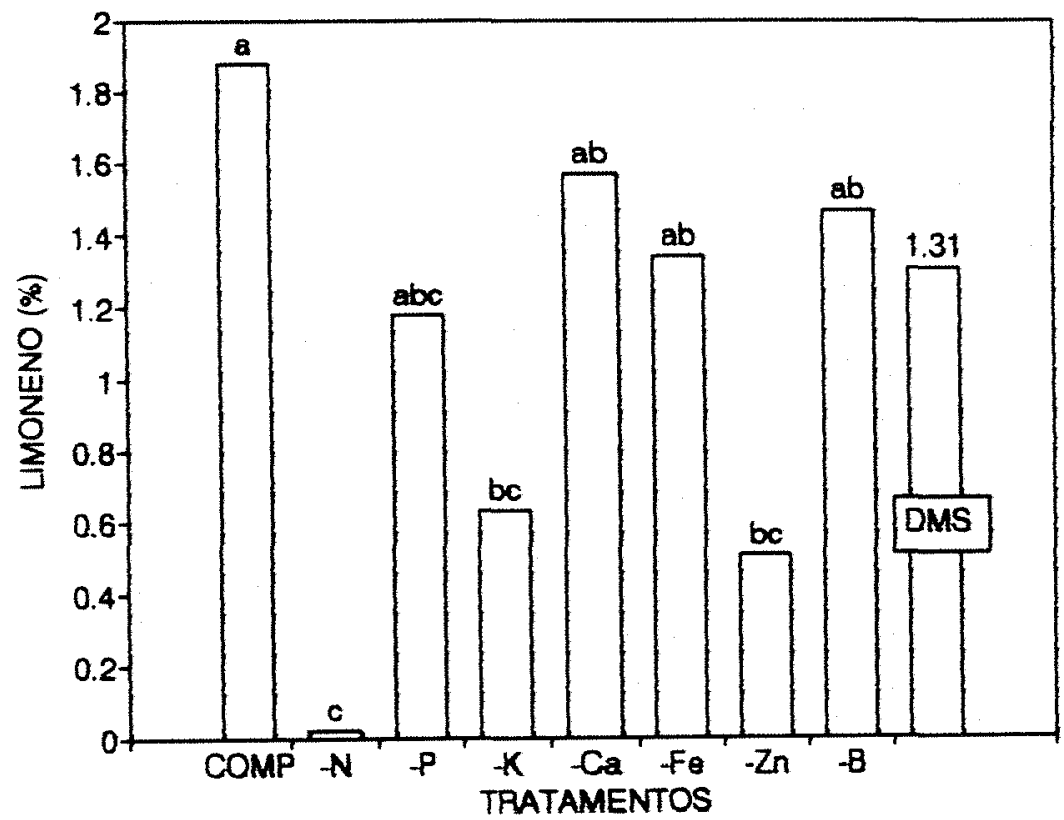

Figura 14. Percentagem de limoneno no óleo das folhas de menta em função dos tratamentos. Barras sob letras iguais não diferem significativamente pelo teste de Tuckey a 5\%. DMS = Diferença Mínima Significativa. 


\subsubsection{Mentona}

O teor de mentona diminuiu com a omissão de nitrogênio e de magnésio na solução nutritiva, comportando-se de modo semelhante ao descrito por SINGH \& SINGH (1989) para nitrogênio e FAROOQI \& MISRA (1983) para magnésio. Mesmo apresentando um baixo coeficiente de variação entre as repetições, a omissão dos demais nutrientes não provocou diferenças significativas em relação ao tratamento completo conforme mostra a Figura 15.

A importância da mentona tende a ser cada vez maior, pois cada vez mais é utilizada e seu preço tem alcançado valores mais interessantes que o próprio mentol, conforme indica a publicação de CLARK (1994).

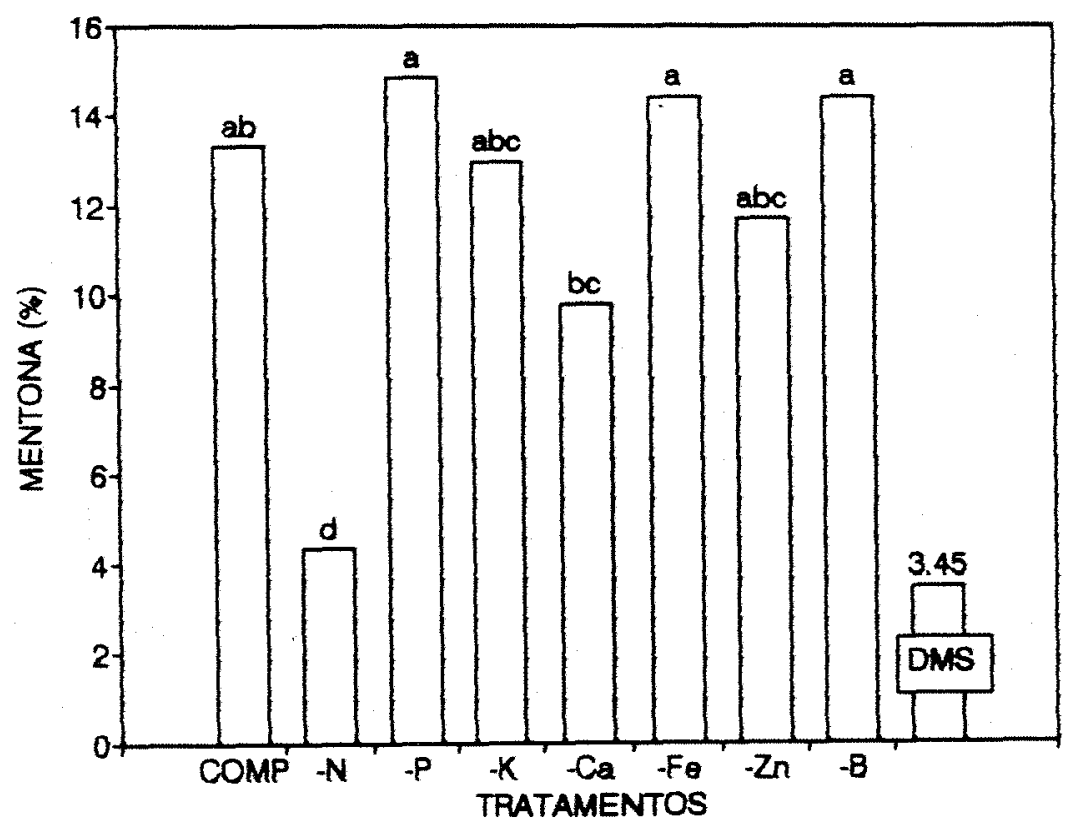

Figura 15. Percentagem de mentona no óleo das folhas de menta em função dos tratamentos. Barras sob letras iguais não diferem significativamente pelo teste de Tuckey a 5\%. DMS = Diferença Minima Significativa. 


\subsubsection{Mentol}

O mentol é a substância encontrada em maior quantidade na composição do óleo essencial da $M$. arvensis, sendo que a variedade IAC-701 foi melhorada com o objetivo de produzir óleo com altos teores dessa substância (SANTOS et al., 1993).

O teor médio de mentol obtido no experimento foi de $62,21 \%$, sendo que o menor valor $(56,14 \%)$ ocorreu no tratamento com solução nutritiva completa, que se distinguiu significativamente dos tratamentos sem zinco e sem fósforo, que produziram óleo com 69,17\% e 68,89\% de mentol respectivamente (Figura 16).

Devido à grande proporção de mentol no óleo, o coeficiente de variação foi o mais baixo de todo o ensaio $(6,81)$. Porém, mesmo com este baixo coeficiente, não foi possivel determinar as variações significativas detectadas por MISRA \& SHARMA (1991a) e SRIVASTAVA \& LUTHRA (1993), quando omitiram o ferro da solução nutritiva e nem na omissão de zinco citada por MISRA \& SHARMA (1991b) e SUBRAHMANYAM et al. (1991). As variações no teor de mentol em função da omissão de nutrientes neste trabalho, foram mais próximas aos dos obtidos por FAROOQI \& MISRA (1983) trabalhando com micronutrientes. 


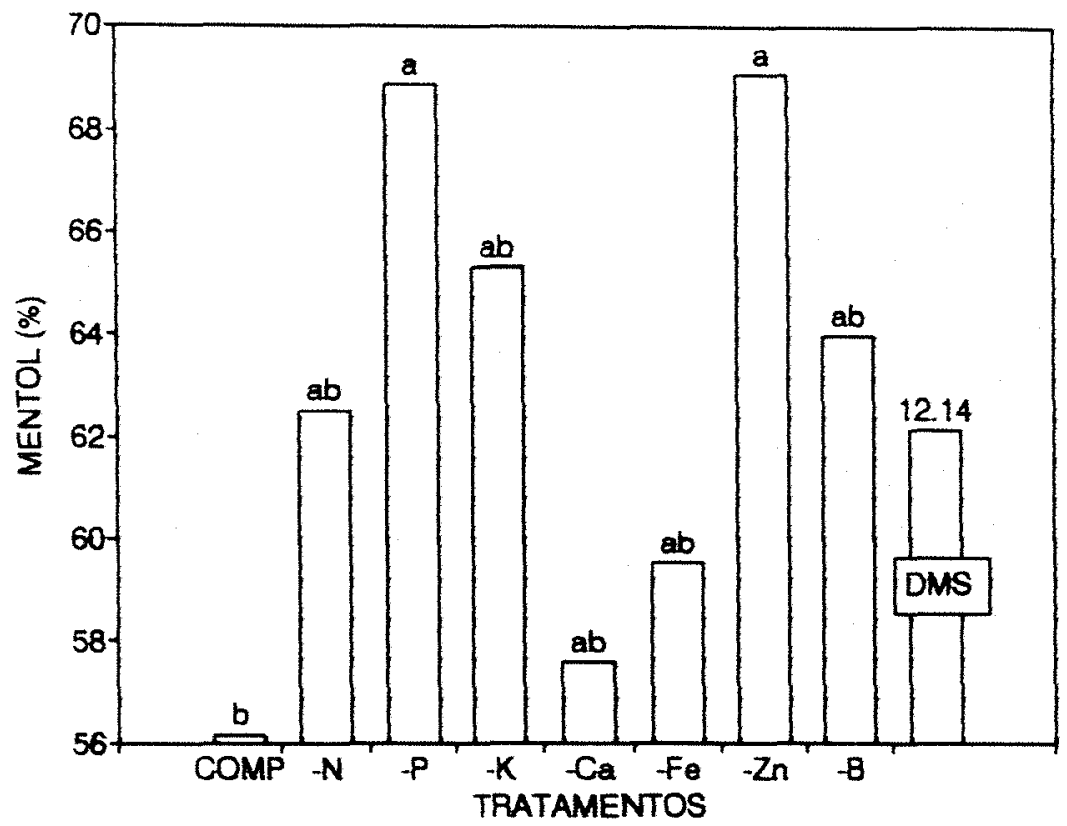

Figura 16. Percentagem de mentol no óleo das folhas de menta em função dos tratamentos. Barras sob letras iguais não diferem significativamente pelo teste de Tuckey a 5\%. DMS = Diferença Mínima Significativa.

\subsubsection{Metil acetato}

A omissão do nitrogênio, do cálcio e do potássio na solução nutritiva fez com que os teores de metil acetato fosse até três vezes maior do que no óleo das plantas que receberam solução completa. No trabalho de SINGH \& SINGH (1989), a diminuição da quantidade de nitrogênio fornecida dobrou a quantidade dessa substância. A Figura 17 mostra as diferenças significativas que a Figura 13 indica. 


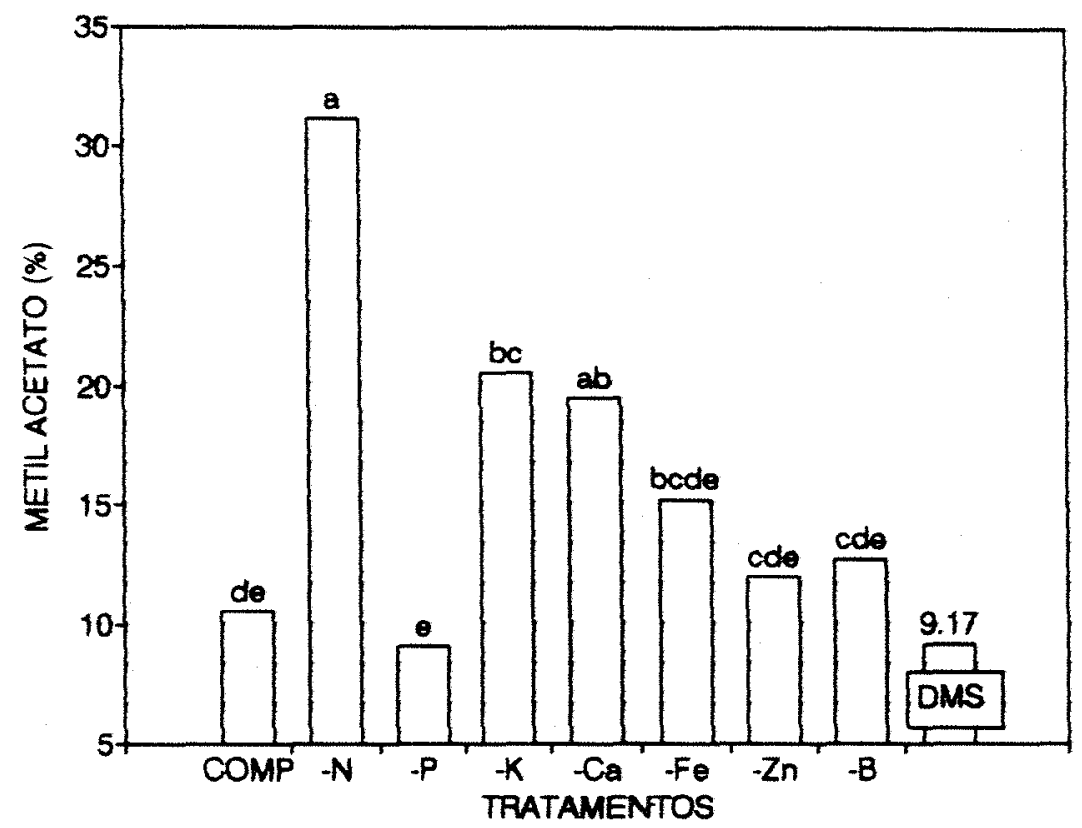

Figura 17. Percentagem de metil acetato no óleo das folhas de menta em função dos tratamentos. Barras sob letras iguais não diferem significativamente pelo teste de Tuckey a 5\%. DMS = Diferença Mínima Significativa. 


\section{CONCLUSÕES}

Os resultados obtidos permitiram chegar-se às seguintes conclusões:

- A omissão dos macronutrientes nitrogênio, fósforo, potássio e cálcio, reduziu significativamente a produção de massa de material verde da planta inteira;

- As proporções de limoneno, mentona, mentol e metil acetato do óleo essencial da Mentha arvensis são alteradas pelas condições de nutrição da planta.

- As soluções nutritivas podem ser utilizadas para a obtenção de óleos com diferentes proporções desses metabólitos. 


\section{REFERÊNCLAS BIBLIOGRÁFICAS}

BATAGLIA， O.C.; FURLANI, A.M.C.; TEIXEIRA, J.P.F.; FURLANI, P.R.; GALLO, J.R. Métodos de análise química de plantas. Campinas, Instituto Agronômico, 1983. 48p. (Boletim Técnico, 78).

BRODERICK, J.J. Mint. Perfumer Flavorist, Wheaton, 18: 51-2, Jan/Feb. 1993.

CANTAGREL, R. \& LABLAMQUIE, O. Application de l'analyse statistique multidimensionelle à la classification des huiles essentialles. Cahiers du Centre D'Exprementation Agriculture Montagne Sèche, Digne les Bains, 1: 77-99, 1986.

CHARLES, D.J.; JOLY, R.J.; SIMON, J.E. Effects of osmotic stress on the essential oil content and composition of 
peppermint. Phytochemistry, Oxford, 29(9): 2837-40, 1990.

CLARK, G.S. Menthol. Perfumer \& Flavorist, Wheaton, 13: 3746, Oct. /Nov. 1988 .

CLARK, G.S. Mentone. Perfumer \& Flavorist, Wheaton, 19: 4145, May./June. 1994.

CLARK, R.J. \& MENARY, R.C. Effects of photoperiod on the yield and composition of peppermint oil. Journal of the American society for Horticultural sciences, Alexandria, 104(5): 699-702, 1979.

CONN, E.E. Preface. In: CONN, E.E., ed. The biochemistry of plants; secondary plant products. New York, Academic Press, 1981. v. 7, p.xix-xx.

DONALISIO, M.G.R.; PINTO, A.J.D.; SOUZA, C.J. Variação na resistência 'à ferrugem e na composição do óleo essencial de dois clones de menta. Bragantia, Campinas, $4(2): 541-7,1985$.

DUHAN, S.P.S.; SINGH, V.P.; BHATTACHRYA, A.K.; HUSAIN, A Response of japanese mint (Mentha arvensis L.) to 
different irrigation schedules. In: INTERNATIONAL CONGRESS OF ESSENTIAL OILS, 7. Kyoto, 1977. Proceedings. Kyoto, Japan Flavor and Fragance Manufactores' Association, 1977. p. 143-5.

EAROOQI, A.H.A. \& MISRA, A. Effect of micronutrients on oil content and plant growth in Mentha arvensis L. var. piperascens Mal. Indian Journal of Plant Physiology, New Delli 26(2): 230- 3, June. 1983.

FINNEMORE, H. The essential oils. London, Ernest Benn, 1926. $880 \mathrm{p}$

FISCHER, G. \& BUSSLER, W. Mikrosymptome des Bor-mangels an Mentha piperita L. z. Pflanzenernaehr, Bodenk, 147: 1320, 1984 .

EISCHER, G. \& HECHT-BUCHHOLZ, C. The influence of boron deficiency on glandular scale development and structure in Mentha piperita. Planta Medica, stuttgart 5: 371$377,1985$.

GREENHALG, P. The markets for mint oils and menthol. London, Tropical Products Institute, 1979. 171p. 
GOMES, F.P. Curso de estatística experimental. Piracicaba, Livraria Nobe1, 1981. 430p.

GUENTHER, E. The essential oils. New York, D. Van Nostrand, 1949. $3 \mathrm{~V} .:$ Individual essential oils of the plant families Rutaceae and Labiatea, 777p.

HERALTH, H.M.W.; IRUTHAYATHAS, E.E.; ORMROD, D.P. Temperature effects on essential oil composition of citronella selections. Economic Botany, New York, $33(4): 425-30,1979$.

HUET, R. L'huile essentielle de menthe au Brésil. Fruits, Paris, $27(6): 469-72,1972$.

KHERA, K.L.; SINGH, B.; SANDHU, B.S.; AUJLA, T.S. Response of japanese mint to nitrogen, irrigation and straw mulching on a sandy-loam soil of Punjab. Indian Journal of Agricultural Sciences. New Delhi, 56(6): 434-8, June. 1986.

KIEFER, H. Exploração de plantas aromáticas e óleos essenciais. In: SIMPÓSIO DE ÓLEOS ESSENCIAIS, 1. , São Paulo, 1985. Anais. Campinas, Fundação Cargill, 1986. p. 15-20. 
KOTHARI, S.K.; SINGH, V.; SHINGH, K. Effect of rates and methods of phosphorus application on herb and oil yields and nutrient concentrations in japanese mint (Mentha arvensis L.). Journal of Agricultural Science, Cambridge, 108(3): 691-3, 1987a.

KOTHARI, S.K.; SINGH, V.; SHINGH, K. Response of japanese mint (Mentha arvensis) to varing levels of nitrogen aplication in Uttar Pradesh foot-hills. Indian Journal of Agricultural Sciences, New Delhi, 57(11): 795-800, Nov. $1987 b$.

LEE, S. \& ARNOFF, S. Boron in plants: a biochemical role. Science, Washington, 158: 798-799, 1967.

LELLIOTT, R.A. \& STEAD,D.E. Methods for the diagnosis of bacterial diseases of plants. In: PREECE, T.F., ed. Methods in plant pathology. Oxford, Blackwell Scientific, 1987. 2 v.: pl-200p.

LIMA, A.R. \& MOLLAN, T.R.M. Nova variedadede Mentha arvensis L. Bragantia, Campinas, 12: 277-84, 1952. 
MAIA, N.B.; BOVI, O.A.; DUARTE, F.R. Obtenção e análise do óleo essencial de gengibre; efeito de secagem e processamento. Bragantia, Campinas, 50(1): 83-92, 1991.

MASSADA, Y. Analysis of essential oils by gas cromatography and mass spectrometry. New York, Halsted Press, 1976. $334 \mathrm{p}$.

MISRA, A. Ultrastructural changes in mesophyll chloroplast of japanese mint (Mentha arvensis L.) under the disorder of Iron nutrition. Photosynthetica, Praha, $24(1): 163-167,1990$.

MISRA, A. \& SHARMA, S. Critical concentration of Iron in relation to essential oil yield and quality parameters of japanese mint. Soil science and Plant Nutrition, Tokyo, $37(2): 185-92,1991 \mathrm{a}$.

MISRA, A. \& SHARMA, S. Critical $\mathrm{Zn}$ concentration for essential oil yield and menthol concentration of japanese mint. Fertilizer Research, The Hague, 29: 261$265,1991 b$.

NAIR, A.K.; SUBRAMANYAM, K.; VERMA, B.S.; SINGH, D.V. Effect of level of fertility, iron and zinc on herbage 
yield and menthol content of japanese mint (Mentha arvensis subsp. haplocalyx var. piperascens). Indian Journal of Agricultural Sciences, New Delhi, 61 (8): 599-600, Aug. 1991.

RAM, M.; YADAV, R.L.; CHATTERJEE, B.N.; SINGH, D.V. Relative efficacy of nitrogen-carriers at different rates and times of application on growth and yield of japanese mint (Mentha arvensis). Indian Journal of Agricultural Sciences, New Delhi, 59(4): 236-41, Apr. 1989 .

SANTOS, S.R. Menta. In: FURLANI, A.M.C. \& VIEGAS, G.P., ed. - melhoramento genético de plantas no Instituto Agronômico. 19.ed. Campinas, Instituto Agronômico, 1993. v. 1, cap. 9, p.355-62.

SARRUGE, J.R. \& HAAG, H.P. Análises químicas em plantas. Piracicaba, USP/ESALQ, 1974. 55p.

SARRUGE, J.R.; Soluções nutritivas. Summa Phytopathologica, Piracicaba, 1(3): 231-3, 1975.

SCHAAD, N.W. Laboratory guide for identification of plant patogenic bacteria. St. Paul, The Americam Phytopathological Society, 1988. 158p. 
SINGH, A.K.; DIKSHIT, A.; DIXIT, S.N. Fungitoxic properties of essential oil of Mentha arvensis var. piperascens. Perfuner Flavorist, Wheaton, 8: 55-8, Feb./Mar. 1983.

SINGH, J.N. \& SINGH, D.P. Effect of phosphorus deficiency on carbohydrate metabolism of Mentha arvensis. Physiologia Plantarum, Copenhagen, 21: 1341-1347, 1968 a.

SINGH, J.N. \& SINGH, D.P. Studies in the mineral nutrition of japanese mint; I influence of phosphorus deficiency on nitrogen metabolism. plant and Soil, The Hauge, 28(2): 363-71, Apr. 1968b.

SINGH， S.P.; CHAND, L.; NEGRI, S.; SINGH， A.K. Antibacterial and antifungal activities of Mentha arvensis essential oil. Fitoterapia, Milano, 63(1): 768, 1992 .

SINGH, V.P. \& SINGH, D.V. Accumulation pattern of chemical constituents in mentha species with advance of crop age and nitrogen level. In: INTERNATIONAL SYMPOSIUM ON MEDICINAL AROMATIC AND SPICES PLANTS, 5., Darjeeling, 
1985. Acta Horticulturae, Wageningen, 188A: 187-9, 1989.

SINHA, N.C. \& SINGH, J.N. Studies in the mineral nutrition of japanese mint; II. Influence of potassium deficiency and seasonal variations on nitrogen metabolism, respiration rate and essential oil content. Plant and Soil, The Hague, 79(1): 51-9, 1984 .

SRIVASTAVA, N.K. \& LUTHRA, R. The relation between primary and secondary metabolism in peppermint under Fe-stress. Journal of Essential Oil, Wheaton, 5: 525-534, Sept./Oct. 1993.

SUBRAHMANYAM, K.; NAIR, A.K.; CHATTOPADHYAY, A.; SINGH, D. Effect of zinc on yield, quality and nutrient composition of japanese mint and avaibility of nutrients in soil. Journal of the Indian Society soil Science, New Delhi, 39: 399-401, 1991. 